\title{
Oxidative Stress, Ageing and Methods of Seed Invigoration: An Overview and Perspectives
}

\author{
Ademola Emmanuel Adetunji ${ }^{1, *(\mathbb{C})}$, Tomi Lois Adetunji ${ }^{2}{ }^{(\mathbb{D}}$, Boby Varghese $^{1}$, Sershen ${ }^{3,4}$ and Norman W. Pammenter ${ }^{1}$ \\ 1 School of Life Sciences, University of KwaZulu-Natal, Durban 4001, South Africa; varghese@ukzn.ac.za (B.V.); \\ pammente@ukzn.ac.za (N.W.P.) \\ 2 Unit for Environmental Sciences and Management (UESM), Faculty of Natural and Agricultural Sciences, \\ North-West University, Private Bag X6001, Potchefstroom 2520, South Africa; lois.olatunji@gmail.com \\ 3 Department for Biodiversity and Conservation Biology, University of the Western Cape, Private Bag X17, \\ Bellville 7535, South Africa; sershenn@gmail.com \\ 4 Institute of Natural Resources, P.O. Box 100396, Scottsville 3209, South Africa \\ * Correspondence: adetunjiademola@hotmail.com
}

check for updates

Citation: Adetunji, A.E.; Adetunji, T.L.; Varghese, B.; Sershen; Pammenter, N.W. Oxidative Stress, Ageing and Methods of Seed Invigoration: An Overview and Perspectives. Agronomy 2021, 11, 2369. https://doi.org/10.3390/ agronomy11122369

Academic Editors: Sara Álvarez and José Ramón Acosta-Motos

Received: 15 October 2021

Accepted: 3 November 2021

Published: 23 November 2021

Publisher's Note: MDPI stays neutral with regard to jurisdictional claims in published maps and institutional affiliations.

Copyright: (c) 2021 by the authors. Licensee MDPI, Basel, Switzerland. This article is an open access article distributed under the terms and conditions of the Creative Commons Attribution (CC BY) license (https:/ / creativecommons.org/licenses/by/ $4.0 /)$.

\begin{abstract}
The maintenance of seed quality during the long-term conservation of plant genetic resources is crucial for averting the projected food crises that are linked to the changing climate and rising world population. However, ageing-induced loss of seed vigour and viability during storage remains an inevitable process that compromises productivity in several orthodox-seeded crop species. Seed ageing under prolonged storage, which can occur even under optimal conditions, induces several modifications capable of causing loss of intrinsic physiological quality traits, including germination capacity and vigour, and stand establishment. The problems posed by seed ageing have motivated the development of various techniques for mitigating their detrimental effects. These invigoration techniques generally fall within one of two categories: (1) priming or pre-hydrating seeds in a solution for improved post-harvest performance, or (2) post-storage reinvigoration which often involves soaking seeds recovered from storage in a solution. Seed priming methods are generally divided into classical (hydropriming, osmopriming, redox priming, biostimulant priming, etc.) and advanced (nanopriming, magnetopriming and priming using other physical agents) techniques. With the increasing popularity of seed invigoration techniques to achieve the much-desired enhanced productivity and resilience in the face of a changing climate, there is an urgent need to explore these techniques effectively (in addition to other important practices such as plant breeding, fertilizer application, and the control of pests and diseases). This review aims to provide an overview of ageing in orthodox seeds and invigoration techniques that can enhance desirable agronomic and physiological characters.
\end{abstract}

Keywords: gene bank; germination; orthodox seeds; priming; reactive oxygen species

\section{Introduction}

Given that global food demand is rising, it is necessary to ensure the conservation of genetic resources to preserve ecosystem resilience and to protect plant biodiversity for future agricultural food production [1,2]. Over a billion people are estimated to be added to the already large world population by 2050 [3]. If no pragmatic response is implemented, the challenge of food security will worsen with the increasing impact of hunger and poverty, particularly in developing countries.

The worrisome, widespread drop in crop yield due to a combination of factors, including, but not limited to, soil degradation and drastic changes in the climate [4,5], and the negative crop production projections across the globe [6,7], all point to a need for another Green Revolution with much more yield and better conservation of resources than the first $[8,9]$. For instance, by the mid-twenty-first century, an increase of up to $60 \%$ in food production is estimated to be needed to feed the growing population $[10,11]$. This 
underscores the need to prioritise various approaches and research interventions towards increased crop production.

Attempts being made to address the identified needs include the development of approaches, such as conservation agriculture, sustainable intensification [12,13], and climatesmart agriculture $[10,11]$, with the aim of raising productivity, decreasing emissions and reducing susceptibility to environmental stresses (i.e., improved resilience). The benefits of the application of cutting-edge techniques, based on investigative research efforts, in various areas of agricultural science, including agroecology, ecophysiology, soil science and plant physiology [14], have been recognised. Addressing the identified needs can be achieved using dynamic approaches involving the application of modern biotechnological and physiological research techniques, among others, geared towards addressing low-crop yield-related challenges, often attributable to the low quality of genetic resources, such as seeds-the principal yield determining factor [15], which forms the subject of this study.

Seed, as a genetic resource, may be regarded as the insurance system for world food schemes. The depletion of this resource exposes the schemes to higher risks, which could ultimately lead to catastrophic failure. Without a systematic approach for the conservation of seed genetic and physiological quality, achieving the much-desired increased productivity and greater resilience in the face of the rising world population and changing climate is a mirage. Moreover, seeds are considered the main basis for the sustenance of humans as plants form over $80 \%$ of the human diet; promoting high-quality seed delivery is thus essential for enhancing crop production and plant tolerance to environmental challenges [15]. Achieving food security largely depends on the seed security of seed-producing communities in all cropping seasons [15]. The application of advances in plant physiology, particularly the various techniques of pre-hydration treatment (which uses priming technology to invigorate debilitated germplasms), in addition to other important components, such as plant breeding for adaptation to climate change and higher yields, and cultural practices (e.g., irrigation, fertilizer application, and control of pests and diseases), is needed to improve seed performance, crop yields, maximum yield, and to enable planting on less favourable land, by making seeds better able to withstand sub-optimal conditions, thereby reducing crop losses. Accordingly, agriculture in this century and subsequently can be more productive and provide for improved conservation of plant genetic resources compared to previous periods. Heightened efforts in this regard, therefore, will ensure that the prospect of reaching millions of the poor with crop production research benefits is achieved [8].

\section{Storage of Orthodox Seeds in Gene Banks}

In terms of conserving plant genetic resources, seed capacity for prolonged storage is particularly essential for gene banks. As far back as 1908, Ewart had grouped seed longevity into short-, medium- and long-term, providing insights into the duration of seed storage before severe viability loss [16]. Later, several experiments testing seed longevity were conducted under artificial and natural sowing conditions. The Beal [17-19] and the Vienna $[20,21]$ germination studies include the oldest (over 100 years) seed longevity studies performed under natural conditions [22]. Other pioneering seed longevity studies [23-25] have shown that moisture content, temperature, relative humidity, and oxygen are the critical factors influencing seed viability and vigour during storage; however, genetic factors and pre-storage conditions are also important [16].

At moisture levels as low as 5\% (fresh mass basis) or less, and at sub-zero temperatures (usually $-18^{\circ} \mathrm{C}$ ) in dry conditions, the mature seeds of some species classified as orthodox can be stored for long periods [26-29]. This is also the easiest method of conserving most spermatophyte genetic resources in conventional gene banks [30], but seeds do not retain their initial quality with extended storage, gradually deteriorating, and inevitably proceeding towards death [31,32]. For instance, seeds that were initially stored in a gene bank at $5{ }^{\circ} \mathrm{C}$ but were later moved to $-18{ }^{\circ} \mathrm{C}$ and stored for between $15-19$ years suffered a decline in germination capacity from $91 \%$ to $11 \%$ in Brassica oleracea and $97 \%$ to $2 \%$ in 
Lactuca sativa [33]. The post-harvest loss of physiological quality of seeds, even when seeds are stored in gene banks, has thus remained a major issue demanding attention for long-term storage [34]. As seeds deteriorate, vigour is first lost, after which comes a loss of viability [35].

Moreover, some species classified as recalcitrant (not covered in this review) have desiccation-sensitive seeds and are not amenable to short or long-term storage under the conditions mentioned above [30]. With the development of cryostorage techniques, involving germplasm storage at ultra-low temperatures (-120 to -196 degrees, [36]), the life span of seeds (including both orthodox and recalcitrant species) can be further extended, but not indefinitely $[33,34,37]$. This implies that though the degree and rate of deterioration of seeds stored under the enhanced conditions of the conventional seed gene banks can be reduced to an appreciable level [32], seed deterioration cannot be completely halted. Walters et al. (2004) showed, by measuring changes in the viability of seeds of several plant species over 20 years of cryostorage, that cryogenic temperatures could not sufficiently stop seed deterioration. They further suggested that there could be as much as a $300 \%$ variation in longevity among species and within accessions stored in these conditions, as the degree of longevity in cryostorage depends on the inherent properties of seeds and seed handling, such as the pre-storage temperature and the year of harvest. This implies that cryostorage temperatures do not completely halt all biological activities; molecules are still sufficiently mobile at these low temperatures to allow ageing reactions to proceed [37].

\section{Germination-Related Physiology}

Under favourable conditions of moisture, warmth, and oxygen, quiescent but viable seed is vivified, forming an actively metabolising structure, in a process described as germination [38]. The progress of germination can be roughly assessed by measuring respiration or water uptake [39], while the completion of germination can be taken to be when the system no longer depends on its stored food [38], or is visibly marked by the protrusion of the radicle [39]. In instances where the radicle may grow before penetrating the surrounding tissues, germination can be taken to have been completed from the time a sustained increase in seed fresh weight is recognised [39]. So, the initiation of germinative activities gradually and eventually leads to the formation of normal, growing seedlings [38].

In cases where a viable seed fails to germinate under favourable germination conditions, dormancy is said to have set in as such seeds require additional conditions, such as a specific light, or temperature regime, or exposure to chemical or physical treatments [39]. Dormant seeds that have been hydrated undergo almost all the metabolic processes that take place during the germination of nondormant seeds, yet the protrusion of the radicle does not occur [40]. Their germination takes place later when the additional conditions required for release from dormancy are met. Three identified stages of seed germination include water imbibition (first stage), nutrient conversion (second stage), and cell elongation and cell multiplication (third stage) [41]. The events following germination, such as the mobilisation of food reserves from the endosperm, supply the much-needed energy for seedling growth until the seedlings become photoautotrophic [42]. The seed germination pattern usually follows a sigmoid curve whereby a few seeds germinate earlier than the others in a population, followed by a rapid rise in percentage germination, and then relatively late germination of a few seeds is recorded. Seed-germination curves are generally right-skewed as the occurrence of more germinations is recorded in the first half of the germination period than the second. Whilst the shape of the curves are generally similar, notable differences in germination patterns are observed among populations [39].

\section{Oxidative Stress in Plants}

Oxidative stress is widely described as a physiological state (response) in cells, tissues and organs, as a result of increased pro-oxidative activities (through the generation of reactive oxygen species (ROS)) compared to antioxidative (enzymic and non-enzymic) activities [43]. This is a consequence of aerobic metabolism during which aerobic organ- 
isms produce incompletely paired, oxygen-containing radicals formed by the unavoidable leakage of electrons onto molecular oxygen during electron transport in the mitochondria, chloroplast, and cell membranes [44]. The generation of ROS may be triggered by severe abiotic and biotic stress conditions [45]. The physiological responses are often characterised by a gradual accretion of various oxidised biomolecules, such as nucleic acids, proteins, lipids, polysaccharides, and metabolites, causing deleterious changes in normal biochemical, mechanical, and physical functions of cell components [43].

Oxidative stress functions, therefore, as an injurious factor. The main mechanisms involve altering the balance between the levels of generated and quenched ROS owing to the upset of regular cellular metabolism, and ROS biosynthesis as a component of developmental processes such as the signalling responses needed for adaptation and defence or programmed cell death [43,46]. Demidchik and Maathuis [47] stated that plants could employ ROS accumulation for encoding and recognising various stress factors, including xenobiotic stressors such as nanoparticles and herbicides that were not recognised before. Stress factors often engender secondary metabolic effects to be overcome by plant tissues for survival and restoration of growth and development [48]. For instance, salinity [49], drought [44], desiccation [50], light [51], temperature [52], and pathogens [46] can induce oxidative stress by increasing the production of free radicals and reactive oxygen species (ROS). Uncontrolled production of ROS can upset the balance of ROS generated during aerobic events and the antioxidative defence system [53], leading to oxidative stress [54].

\subsection{Biochemical Effects of Ageing and Oxidative Stress in Seeds}

Oxidative stress has been implicated in the loss of vigour in plant tissues [55]. Loss of vigour in plant tissues is a fundamental physiological phenomenon observed when plant tissues are exposed to environmental stress of any type (abiotic and biotic) under suboptimal external (both agricultural and natural) conditions [56]. It is a pressing global challenge for modern agriculture. Both abiotic and biotic factors can cause oxidative stress [57], which is widely described as the physiological state (response) brought about by increased pro-oxidative activities (through a gradual generation and accumulation of reactive oxygen species (ROS)) over antioxidative (enzymic and non-enzymic) activities $[43,58]$. In B. oleracea, for instance, seed deterioration has been related to changes in the levels of electrolyte leakage [59], proline, proteins, soluble sugars, and phenolic compounds [60]. However, Golovina et al. [61,62] reported no change in protein secondary structure in some seeds of orthodox species stored for 20 to 30 years, including Allium cepa, Raphanus sativus, Cucumis melo, Capsicum annuum, and Brassica napus, despite the loss of membrane integrity. In L. sativa, seed deterioration has been attributed to changes in the levels of lipid hydroperoxides [63] and volatile products such as aldehydes and alcohols [64]. Of these environmental conditions, abiotic stress is recognised to constitute a major drawback to crop farming $[65,66]$, accounting for an approximately $51-82 \%$ loss of potential crop yield worldwide $[56,67]$. In many cases, abiotic stressors engender secondary metabolic effects that need to be overcome by plant tissues for survival and restoration of growth and development [48]. For instance, salinity [49], drought [44], light [51] and temperature [52] induce oxidative stress by increasing the production of free radicals and ROS, thereby offsetting the balance of ROS generated during metabolic events and the defence system [53]. The impacts of oxidative stress are usually expressed in relation to the overall growth of the plant, including vigour, yield, biomass accumulation or primary assimilation events [56], as well as in terms of the quality of seed [68].

Seeds, due to their rich genetic diversity, are considered the most efficient natural means of protecting the variability of genetic material, in comparison to somatic tissues. The challenge of loss of vigour creates a severe threat [69] which risks the conservation of millions of genetic materials kept in several world gene banks [70], making the understanding of loss of vigour, and consequential seed ageing in storage, vital for plant physiologists. Seed ageing has been intimately linked to oxidative stress involving ROS which are highly 
reactive, toxic, and capable of causing degradative reactions of several biomolecules over an extended storage period $[69,71]$. Biological molecules, including carbohydrates, lipids, proteins, and polynucleic acids, such as DNA and RNA, are believed to be the main ROS targets during oxidative stress [43,72]. The physiological lesions that result include loss of membrane integrity (through lipid peroxidation), reduced respiration, enzyme inactivation and degradation, and genetic degradation $[31,73,74]$, leading to severely damaging effects on seed vigour, viability and germinability, especially.

\subsection{Oxidation of Major Biological Molecules}

\subsubsection{Lipids}

Among other affected biomolecules, ROS-mediated oxidation of polyunsaturated fatty acids (lipid peroxidation) is the most harmful as it can cause chain reactions involving the formation and spread of ROS [75]. Lipid peroxidation is suggested to be a significant bioindicator of oxidative stress [76]. The damaging effect is irreversible, causing severe degradation of the membrane, inactivation of enzymes, total loss of membrane-bound protein activities, and cell death [43]. Lipid peroxidation has been implicated in the loss of viability during storage of seeds of many crop species $[77,78]$ and has been shown to lead to swelling of mitochondria, increased membrane viscosity and heightened bilayer permeability (measured as increased solute leakage) [31,79]. Products of lipid oxidation can also cause DNA damage and interrupt the normal functioning of several cellular systems $[79,80]$.

With respect to mechanisms, lipid peroxidation can occur via non-enzymic and enzymic processes $[75,81]$. The non-enzymic, ROS-mediated, process of lipid peroxidation entails an activation (initiation) stage involving ROS generation, a distribution (propagation) stage involving ROS chain reactions, and a termination stage in which non-radical products are formed [75,82]. The peroxidation initiation stage is activated by the removal of a hydrogen atom from a methylene $\left(-\mathrm{CH}_{2}-\right)$ group, leaving behind $-{ }^{\bullet} \mathrm{CH}-$ (lipid radical), by sufficiently reactive species such as alkoxyl $\left(\mathrm{RO}^{\bullet}\right)$, hydroxyl radicals $\left(\mathrm{HO}^{\bullet}\right)$, peroxyl radicals $\left(\mathrm{ROO}^{\bullet}\right)$, hydroperoxyl $\left(\mathrm{HO}_{2}^{\bullet}\right)$ and peroxynitrite, but not superoxide $\left(\mathrm{O}_{2}^{\bullet-}\right)$ or hydrogen peroxide $\left(\mathrm{H}_{2} \mathrm{O}_{2}\right)$. Saturated and monounsaturated fatty acids, for example, oleic acid, with one double bond and 18 carbon atoms, can be subjected to oxidation reactions but not the chain reaction of lipid peroxidation, as they are less vulnerable [75,83]. However, the polyunsaturated fatty acids of cellular membrane phospholipids contain double bonds, which make them susceptible to peroxidation by the facilitation of hydrogen atom removal $[43,82,84]$. The lipid radicals formed then trigger $\mathrm{O}_{2}$-mediated chain reactions involving the formation of lipid peroxyl radicals $\left(\mathrm{LOO}^{\bullet}\right)$, which in turn abstract hydrogen atoms from nearby fatty acid molecules forming a stable intermediate lipid hydroperoxide $(\mathrm{LOOH})$ and another lipid radical in the propagation phase $[43,83]$. The process is limited by the termination reaction phase producing non-radical products. In addition, non-radical peroxidation of lipids can occur by polyunsaturated fatty acids reacting with singlet oxygen $\left({ }^{1} \mathrm{O}_{2}\right)$ forming $\mathrm{LOOH}$ without production of intermediate radicals [85-88]. Though reasonably stable, lipid peroxides may be decomposed by metal complexes in a reaction catalysed by transition metals producing radicals that can reinitiate peroxidation via redox cycling of the metal ions, forming products, such as 4-hydroxy-2-nonenal (4HNE), 4-hydroxyhexenal (4-HHE), and malonaldehyde (MDA), which are useful and extensively studied biomarkers of lipid peroxidation $[75,82,83,89]$. These aldehydes, in turn, bind with DNA or protein, causing more severe damage [90]. Loss of membrane integrity, breakdown of organelles, oxidation and impairment of DNA, RNA, and proteins result where there is severe lipid peroxidation reaction [76,88]. Of these aldehydes, 4-HNE is considered the key product of the peroxidation of omega- 6 fatty acids, such as linoleic acid (C18:2, n-6) and arachidonic acid (C20:4, n-6). The production of 4-HHE, the aldehyde thought to induce the permeability of mitochondrial inner membrane [91] and upset metabolic events [92], has been reported from the peroxidation of omega- 3 fatty acids, such as $\alpha$-linolenic acid (C18:3, n-3) and docosahexaenoic acid (C22:6, n-3) [83]. 
In enzymic peroxidation, dioxygenases including lipoxygenases (LOX enzymes) are considered the key oxidising enzymes of polyunsaturated fatty acids, with linoleic acids (C18:2 and C18:3) as the major substrates [81,93]. In plants, LOX enzymes can add an oxygen molecule at carbon 9 or 13 of C18-fatty acids [81], forming 9- and 13-hydroperoxyl derivatives of linoleic acid, respectively [94]. The involvement of LOX enzymes in the ageing-induced lipid peroxidation of seeds has been investigated in several species where it was demonstrated that absence or lowering of LOX enzyme activity decreased the levels of MDA (Zea mays [95]), MDA and LOOH (Oryza sativa seeds [96]) promoted storability and germination (Oryza sativa seeds [97]), and improved vigour and viability (Nicotiana tabacum [98]).

\subsubsection{Proteins}

Since reactive oxidants can be indiscriminately generated in cells, especially at a heightened rate during abiotic or biotic stress, proteins are also a major target biomolecule $[99,100]$, as they are abundant and readily reactive with several oxidants [101]. Proteins constitute about $68 \%$ of oxidised biomolecules [99,102]; thus, protein oxidation is a useful bioindicator of oxidative stress [100]. Defined as a covalent alteration of proteins by reactive oxidants or oxidative stress spinoffs [100], the ROS-mediated oxidation of proteins has been described extensively [103-106]. Protein oxidation often occurs even under normal physiological circumstances indicating that it is not always an injurious plant process [75,107]. Avery (2011) suggested that some proteins are more vulnerable to oxidation than others due to factors such as more easily oxidised amino acid residue content, metal-binding sites, the localisation of protein within cells, molecular conformation, and degradation rate. It is becoming increasingly clear that newly synthesised proteins are highly susceptible to post-synthesis oxidative degradation, suggesting that attaining and conforming to a stable multimeric protein complex may be protective against oxidative injury $[108,109]$. The oxidation of protein can facilitate the build-up of toxic non-native proteins capable of inducing programmed cell death in severe cases [43,75]. The production of unstable intermediates and the formation of stable products are useful for the estimation of protein damage [101]. ROS-induced protein injury can vary since protein properties are not all equivalent. The extremely reactive $\mathrm{ROS}, \mathrm{HO}^{\bullet}$, usually generated from $\mathrm{H}_{2} \mathrm{O}_{2}$ via the Fenton reaction, often leads to non-specific oxidation, unlike the specific type caused by other ROS [75]. Other ROS causing oxidation of proteins include the radicals of alkoxyl $\left(\mathrm{RO}^{\bullet}\right)$, hydroperoxyl $\left(\mathrm{HO}_{2}{ }^{\bullet}\right)$, peroxyl $\left(\mathrm{RO}_{2}{ }^{\bullet}\right)$, superoxide $\left(\mathrm{O}_{2}{ }^{\bullet-}\right)$ and non-radical species, such as hypochlorous acid $(\mathrm{HOCl})$, hydrogen peroxide $\left(\mathrm{H}_{2} \mathrm{O}_{2}\right)$, ozone $\left(\mathrm{O}_{3}\right)$, peroxynitrite $\left(\mathrm{ONOO}^{-}\right)$, and singlet oxygen $\left({ }^{1} \mathrm{O}_{2}\right)[75,110]$. While the oxidation of certain amino acids (e.g., those containing sulphur) is reversible, most ROS-mediated modifications are characterised by irreversible loss or inactivation of the parent amino acid residue, and catalytic, metabolic, regulatory, structural, or other activities and functions leading to protein damage or elimination $[43,101,111]$. Irreversible amino acid modifications, such as to arginine and lysine, tryptophan and tyrosine, the production of dityrosine, and protein-to-protein cross-linking, are in most cases accountable for the permanent shutdown of function of the affected proteins which are later degraded [111]. The reversible types of amino acid modification, such as S-nitrosylation and glutathionylation, may play a redox regulatory role protecting cysteine from irreversible oxidation, as well as modulating protein function $[100,111]$. The main oxidative modifications of proteins are outlined in Table 1.

Table 1. Commonly reported ROS-induced modifications of polyunsaturated fatty acids (PUFA), proteins, carbohydrates, and DNA.

\begin{tabular}{cc}
\hline \multicolumn{2}{c}{ Examples of commonly reported ROS-induced modifications of PUFA [100] } \\
\hline PUFA & Oxidised product \\
\hline Linoleic acid (18:2) & $\begin{array}{c}\text { 4-HNE } \\
\text { Linolenic acid (18:3) }\end{array}$ \\
$\begin{array}{c}\text { Cyclic oxylipin, hydroxyoctadecatrieonic } \\
\text { acid, MDA }\end{array}$ \\
\hline
\end{tabular}


Table 1. Cont.

\begin{tabular}{|c|c|}
\hline \multicolumn{2}{|c|}{ Examples of commonly reported ROS-induced modifications of proteins $[43,100,112,113]$} \\
\hline Amino acid & Oxidised product \\
\hline Cysteine & Cysteic acid (cysteine sulfonic acid) \\
\hline Methionine & Methionine sulfone \\
\hline Arginine, Lysine, Proline, Threonine & $\begin{array}{l}\text { Carbonyls (ketones, aldehydes): aminoadipic semialdehyde, pyrrolidone, } \\
\text { acrolein, 4-HNE, MDA, glu } \gamma \text {-semialdehyde, } 2 \text {-amino-3-ketobutyric acid }\end{array}$ \\
\hline Glutamyl (glutathione, glutamine, glutamate) & Pyruvic acid, oxalic acid \\
\hline Histidine & 2-Oxohistidine, 4-HNE, aspartate, asparagine \\
\hline Phenylalanine & Hydroxyphenylalanines \\
\hline Tryptophan & Kynurenine \\
\hline Tyrosine & 3-Nitrotyrosine \\
\hline \multicolumn{2}{|c|}{ Examples of commonly reported ROS-induced modifications of carbohydrates $[100,114]$} \\
\hline Sugar & Oxidised product \\
\hline Aldohexose, polyol & Aldopentose, formic acid \\
\hline \multicolumn{2}{|c|}{ Examples of commonly reported ROS-induced modifications of DNA [100] } \\
\hline DNA & Oxidised product \\
\hline Purines (e.g., guanine) & 8-Hydroxyguanine, FapyGua \\
\hline
\end{tabular}

The most common mechanisms of ROS-mediated protein damage involve the direct metal-catalysed oxidation (primary carbonylation) of S-containing amino acid residues such as:

(1) cysteine (Cys) to produce cystine (disulfide), which is further oxidised through cysteine sulfenic acid to form cysteine sulfinic acid; these initial stages are reversible until the highest oxidation and damaging level where cysteic acid is irreversibly formed [43,100,111];

(2) methionine (Met) to produce methionine sulfoxide. This stage is also reversible, but the final stage of Met oxidation to sulfone seems to be damaging and irreversible [100]; and

(3) most of the other amino acids, especially arginine (Arg), lysine (Lys), proline (Pro), and threonine (Thr) form stable aldehydes or ketones (carbonyls) in an irreversible reaction $[75,100,112]$ that is not particular to any oxidants $[113,115]$. Thus, the extent of reactive oxidant-induced modification of proteins is generically measured as protein carbonyl [113,116,117].

Carbonyl formation (protein carbonylation, (PC)) demands higher energy inputs than the oxidation of other AA residues and leads to deleterious alterations of protein structure and function [43]. Secondary carbonylation reactions may occur by the reaction of proteins with aggressive lipid peroxidation products, such as 4HNE and MDA [43,75]. In addition, carbonyl formation can result from protein glycation or glycoxidation $[118,119]$, which may be a confounding factor in using carbonylation as an exclusive oxidation biomarker [113], or by direct protein backbone oxidation forming protein fragments with an $\mathrm{N}$-terminal $\alpha$-ketoacyl amino acid residue [111]. All these processes severely alter or inhibit the physiological and enzymatic activities of protein [43]. Heightened PC has been reported for several plant oxidative stresses [120] induced by salinity [121,122], dehydration [116,123], heavy metals [124,125], pathogen attack [126,127], and ROS-induced seed ageing [128,129].

\subsubsection{Carbohydrates}

Studies on the oxidative modification of carbohydrates have received less attention even though carbohydrates are considered more abundant than the other plant biomolecules [43]. As with other biomolecules, the oxidative modification of carbohydrates may be injurious to living systems [43]. Free polyols, such as mannitol, pinitol and sorbitol [130], and sugars, are oxidised by $\mathrm{HO}^{\bullet}$, mainly forming formic acid [100]. Miller [131] stated that arabinogalactan, cellulose, pectin, and similar polysaccharides 
in the cell wall could be broken down by $\mathrm{HO}^{\bullet}$. The auxin-mediated extension of cells induces the generation of ROS, which is used by cell wall-bound peroxidases to produce $\mathrm{HO}^{\bullet}$ near scission sites $[100,132]$. Moreover, cell wall $\mathrm{Cu}^{2+}$ reduced to $\mathrm{Cu}^{+}$by $\mathrm{O}_{2}{ }^{\bullet-}$ and ascorbate can produce $\mathrm{HO}^{\bullet}$ by reacting with apoplastic $\mathrm{H}_{2} \mathrm{O}_{2}$ [133]. The $\mathrm{HO}^{\bullet}$ formed causes non-enzymatic separation of pectins and xyloglucans, leading to loosening of the cell wall $[43,133]$. Similar Fenton reactions of $\mathrm{H}_{2} \mathrm{O}_{2}$ with $\mathrm{Cu}$ or Fe might substantially increase under stress conditions, leading to deleterious effects $[43,134]$. On the other hand, simple sugars, disaccharides $[43,135]$ and some osmoprotectants (e.g., mannitol, sorbitol, proline, and myo-inositol) may be capable of scavenging ROS, such as $\mathrm{HO}^{\bullet}$ [130]. Increased levels of carbohydrate, such as mannitol, sucrose, and glucose have been correlated with oxidative stress resistance in several species of plant $[136,137]$; however, there is a dearth of information on the direct connection between the physiology of plants and the ROS-induced oxidation of carbohydrates [43].

\subsubsection{Polynucleotides}

The oxidative modification of DNA is often implicated in the ageing of seeds $[69,138]$ and, in some cases, perennial plants [43]. Essentially, ROS attack on DNA causes chemical modification of bases, fragmentation of deoxysugar, and breaking of strands [139]. Again, $\mathrm{HO}^{\bullet}$, being the most reactive, are particularly harmful to polynucleic acids (DNA and RNA) [43]. $\mathrm{HO}^{\bullet}$ attaches to double bonds of nucleotide bases and abstracts $\mathrm{H}^{+}$from $2^{\prime}$ deoxyribose (resulting in sugar damage) [139] and $-\mathrm{CH}_{3}-$ of thymine [43]. $\mathrm{HO}{ }^{\bullet}$ can also oxidise purines, forming products such as 7-hydro-8-oxoguanine (8-oxoG). The formation of 2,6-diamino-4-hydroxy-5-formamidopyrimidine (FapyGua) has also been reported as a product of polynucleic acid oxidation $[43,139]$. Guanine is often attacked by ${ }^{1} \mathrm{O}_{2}$, but not $\mathrm{O}_{2}{ }^{\bullet-}$ and $\mathrm{H}_{2} \mathrm{O}_{2}$, to form 8-Hydroxyguanine [100]. ROS-modification of DNA can be both direct and indirect. Often, MDA (a breakdown product of PUFA) conjugation with guanine leads to the formation of an additional ring [100,140]. DNA impairment has both cytotoxic and genotoxic effects [141]. Besides mutations, DNA oxidation can cause alterations of cytosine methylation required for the regulation of gene expression [100]. Repair mechanisms of the oxidative damage of plant DNA include directly reversing the impairment caused as well as replacing the base or even the entire nucleotide [100,142,143]. A defence system, both in cytosol and organelles, may also be implemented as a form of protection [43]. Under oxidative stress, however, nuclear ROS-scavengers (glutathione and peroxiredoxin) inadequately protect the DNA [100,142]. Enzymes such as catalase and ascorbate peroxidase in the cytosol are required to protect nuclear DNA in such conditions $[43,144]$.

\subsection{Cellular Generation of Reactive Oxygen Species (ROS)}

Reactive oxygen species are produced at several locations in the cells, such as chloroplasts, mitochondria, the plasma membrane, peroxisomes, apoplast, the endoplasmic reticulum, and the cell wall. Conventionally, it is believed that ROS are unavoidably produced during metabolic processes of aerobic systems [145]. Several possible sources of ROS have been identified in plants, including reactions involving normal plant metabolisms such as photosynthesis [46] and mitochondrial respiration [72]. There are other ROS sources as well, which are produced from abiotic stress-induced pathways. For example, during photorespiration, the oxidation of glycolate by glycolate oxidase in peroxisomes accounts for the majority of ROS, such as hydrogen peroxide [46]. Recently, more plant ROS sources have been recognised, such as plasma membrane-bound peroxidases, amine oxidases, and nicotinamide adenine dinucleotide phosphate (NADPH) oxidases, involved in events such as apoptosis and defence against pathogens [146]. While a low level of cellular ROS is formed under normal growth conditions, ROS formation is heightened under stress conditions [46].

Various enzymes (e.g., oxygenases) and non-enzymic processes "fix" oxygen atoms into various biological molecules [147]. Partly reduced forms of molecular oxygen $\left(\mathrm{O}_{2}\right)$, 
resulting from $\mathrm{O}_{2}$ excitation to produce singlet oxygen $\left({ }^{1} \mathrm{O}_{2}\right)$, or from the transfer of one electron to $\mathrm{O}_{2}$ forming the superoxide radical $\left(\mathrm{O}_{2}{ }^{\bullet-}\right)$, two electrons to $\mathrm{O}_{2}$ forming hydrogen peroxide $\left(\mathrm{H}_{2} \mathrm{O}_{2}\right)$, or three electrons to $\mathrm{O}_{2}$ forming the hydroxyl radical $(\mathrm{HO} \bullet$ [46], are more readily reactive than atmospheric oxygen. Hence, they are termed reactive oxygen species [58]. These ROS can cause unrestrained oxidation of various biomolecules leading to oxidative cellular damage [46]. Metabolically active organelles, such as the mitochondria, peroxisomes and chloroplasts, processing extremely oxidising reactions, or that have high electron flow rates, are the primary ROS sources within cells [148]. Ubiquinone-cytochrome complexes I and III of the electron transport chain (ETC) are the main sites of $\mathrm{O}_{2}{ }^{\bullet-}$ production in mitochondria, while photosystems I and II are the main sites of ${ }^{1} \mathrm{O}_{2}$ and $\mathrm{O}_{2}{ }^{\bullet-}$ production in chloroplasts [148].

\subsubsection{The Dual Capacity of ROS}

Though ROS are harmful when in excess, they are beneficial in cellular processes, such as signalling, cellular differentiation and proliferation [72], ion transport, and gene expression [149], when produced in moderation. While plants can employ the ROS steadystate concentration to monitor stress levels within cells, this must be tightly controlled to avoid over-accretion of ROS that can cause cell death [146]. The ROS-induced death of cells can occur as a result of oxidative modifications of biomolecules, such as enzymes, DNA, RNA, proteins, and membrane lipids (the classical concept). On the other hand, heightened ROS levels can trigger programmed cell death, which has been shown by anti-apoptotic genes suppression of paraquat-induced oxidative stress cell death in Nicotiana tabacum [46]. Further, some cell death, earlier believed to be directly caused by oxidative stress, is now regarded as programmed cell death, consistent with the view that ROS can have beneficial effects on plants, promoting physiological function, cellular proliferation, and viability [72]. In essence, plants require a regulatory system to ensure low ROS concentration, and another to allow for the quenching of surplus ROS production [46]. Balancing the different steady-state ROS level and generated ROS types, as driven by the interaction of different ROS-generating and ROS-quenching systems, is also important. The balance may be altered significantly depending on the physiological state of the plant and the combination of various biochemical, developmental, and environmental stimuli [46]. Apart from aggravating cellular impairment, ROS can stimulate the expression of defence genes. ROS, such as $\mathrm{O}_{2}{ }^{--}$or $\mathrm{H}_{2} \mathrm{O}_{2}$, can separately or jointly induce various genes, thereby allowing for more ROS signalling flexibility. Furthermore, reports on plant responses to abiotic stress show that ROS may be involved in regular signalling for adaptation to stress [146].

\subsubsection{ROS Scavenging in Plant Cells}

The main plant defence system against ROS involves the activities of antioxidants -compounds that can protect cells from oxidative injury even when present in low quantity [149]. These antioxidants can be either enzymatic or non-enzymatic. Major enzymic antioxidants include

(1) Superoxide dismutases (SODs): These are ubiquitous metalloenzymes involved in essential defence against superoxide [149] via a redox cycle where the active site metal is deoxidised by one $\mathrm{O}_{2}{ }^{\bullet-}$ radical and re-oxidised by another [150]. The three (3) forms of identified SOD, defined by the active site metals, are iron-SOD, copper and zinc-SOD, and manganese-SOD [151]. SOD catalyses the dismutation of $\mathrm{O}_{2}{ }^{\bullet-}$ to $\mathrm{O}_{2}$ and $\mathrm{H}_{2} \mathrm{O}_{2}$ [147], which can then be broken down by other essential enzymesthe catalases.

(2) Catalases (CATs): These are peroxisome-localised, heme-group-containing enzymes [152], though their presence has also been reported in mitochondria [153]. They are involved in the breakdown of $\mathrm{H}_{2} \mathrm{O}_{2}$ to $\mathrm{H}_{2} \mathrm{O}$ and $\mathrm{O}_{2}$ [147]. They are recognised as essential defence enzymes against ROS-induced oxidative stress [154,155]. In addition, they are involved in plant defence and metabolism as well as the perception of cellular signals [156]. 
(3) Glutathione reductases (GRs): These flavoproteins occur mostly in the chloroplasts but have also been reported in the cytosol, mitochondria, and peroxisomes [157]. They are extremely specific and are involved in the reduction of oxidised glutathione (GSSG) back to the reduced form (GSH) using NADPH as the reductant [147], thereby sustaining a high GSH to GSSG ratio [158]. They sustain the reduced state of GSH through the ascorbate-glutathione cycle and are involved in maintaining the $-\mathrm{SH}$ group and act as a substrate for glutathione-S-transferases. In conjunction with superoxide dismutase and ascorbate-glutathione pathway enzymes, GRs constitute an important ROS scavenger [158]. They have been demonstrated to enhance oxidative stress tolerance in transgenic Nicotiana tabacum [157].

(4) Ascorbate peroxidases (APXs): These heme-containing enzymes are also involved in the decomposition of $\mathrm{H}_{2} \mathrm{O}_{2}$ using ascorbate as a reductant [159]. Different isoforms have been reported in the cytosol, chloroplast, mitochondria, thylakoid, stroma, and peroxisome $[152,159,160]$. Increased APX activity has been reported under abiotic stress such as light [161], drought and heat [162], and heavy metal contamination [163].

(5) Glutathione peroxidases (GPXs): These are non-heme-containing antioxidant enzymes [159] using glutathione as a reductant [164]. They are ubiquitous and predicted to be localised in cytosol, chloroplast, endoplasmic reticulum, mitochondria and plastids [165]. They have been demonstrated to play a role in lipid hydroperoxide detoxification, plant defence, and response to biotic [166] and abiotic stresses [164].

A balance between the activities of antioxidant enzymes such as APX, CAT, and SOD is necessary to determine the steady-state $\mathrm{ROS}$ (e.g., $\mathrm{O}_{2}{ }^{\bullet-}$ and $\mathrm{H}_{2} \mathrm{O}_{2}$ ) level [46]. In addition to metal ion sequestration, this balanced activity is considered crucial to forestalling the production of the extremely toxic $\mathrm{HO}^{\bullet}$ through the metal-dependent Fenton or HaberWeiss reactions [46]. APX and CAT are thought to be of different groups of $\mathrm{H}_{2} \mathrm{O}_{2}$ scavengers due to their different affinity for $\mathrm{H}_{2} \mathrm{O}_{2}$ ( $\mu \mathrm{M}$ and $\mathrm{mM}$ range, respectively). Ascorbate peroxidase can reduce $\mathrm{H}_{2} \mathrm{O}_{2}$ to very low concentrations and is conceivably involved in ROS modulation for signalling, while the main role of CAT is to scavenge excess ROS under stress [46]. Since CAT is not reductant dependent to play its role, it might not be sensitive to cell redox status, contrary to the other systems [46]. Interestingly, some intricate interactions between the mechanisms generating ROS and those scavenging ROS have been reported in transgenics having repressed ROS-quenching systems. Plants having repressed APX formation have their CAT, GR, and SOD induced to compensate for the absence of APX, while plants having inhibited CAT compensate for it by inducing other antioxidant enzymes, such as GPX and APX, suggesting some level of redundancy [167].

The non-enzymic antioxidants also play vital roles in the antioxidant defence system, which forms a strong basis for their use as indicators of stress [148]. Major non-enzymic antioxidants include:

(1) Ascorbic acid (AA): AA is known to be abundant and one of the most potent antioxidants involved in $\mathrm{ROS}$ (e.g., $\mathrm{O}_{2}{ }^{\bullet-}$ [168]) detoxification and prevention [148,149]. This water-soluble antioxidant is found in all cellular compartments and at higher concentrations in photosynthetic cells [46]. AA is mostly present in its reduced form [169]. It is crucial for the maintenance of membrane structure and capable of completely preventing lipid peroxidation initiation, scavenging ROS, such as singlet oxygen, hydroperoxyl radicals, superoxide, and peroxynitrite, and protects other substrates from oxidative impairment $[148,149]$. In addition, AA has been documented to be involved in ROS scavenging by controlling redox balance in cells [170]. AA has been reported to enhance abiotic stress tolerance $[169,171]$. AA is involved in the modulation of the synthesis of tocopherol [172] and the regulation of plant defence responses over and above developmental processes [173].

(2) Glutathione (GSH): In addition to AA, GSH is another non-enzymic antioxidant involved in the detoxification of ROS [168]. Both GSH and AA are involved in the ascorbate-glutathione cycle, where ascorbate peroxidase plays a role in the direct removal of $\mathrm{H}_{2} \mathrm{O}_{2}$ [174], singlet oxygen [148] and hydroxyl radical [175]. AA is most 
abundant in its reduced and active form and found in various cellular compartments, including the cytosol, mitochondria, endoplasmic reticulum, vacuole, peroxisomes, apoplast, and chloroplasts [176]. GSH provides a substrate for several reactions forming oxidised glutathione (GSSG). Balanced GSH to GSSG levels are key to maintaining a redox state in cells [177]. A decline in GSH levels during stress often leads to an imbalanced redox state, thereby causing system deterioration [178]. Heightened biosynthesis of GSH in chloroplasts, instead of protecting cells, may cause oxidative impairment, perhaps by adjusting the general redox state of chloroplasts [179]. It has been reported that the ratio of reduced to oxidised antioxidants can signal the modulation of ROS-scavenging mechanisms [46,51]. GSH plays a major role in protection from oxidative attack on biological membranes [149] and participates in various physiological events, including sulphate transport regulation, xenobiotics detoxification, and signal transduction [148]. Heightened GSH level has been linked with plants' ability to withstand oxidative stress [180].

(3) Tocopherol (vitamin E): This lipophilic phenolic compound exists in eight similarly potent forms as alpha $(\alpha)-$, beta $(\beta)-, \operatorname{gamma}(\gamma)$ - and delta $(\delta)$ - tocotrienols and tocopherols [181]. It forms part of the biological membrane, playing both non-antioxidant and radical-chain-breaker functions [181]. It is regarded as a potential ROS and lipid radical scavenger [182]. Reduction in tocopherol levels following seed ageing suggests that it is involved in protection against oxidative stress-induced impairments [183], thus making it a useful indicator of seed deterioration [149]. Its synthetic analogue, trolox, has also been reported to be similarly capable of preventing oxidative impairment [184]. Trolox has some advantages in being moderately soluble in water [185]. Unlike $\alpha$-tocopherol, trolox may be integrated directly into both lipid and water parts of cells [184], thus making it suitable for conducting studies involving both living systems and model systems [185]. The antioxidant power of trolox has been reported to be much more than that of $\alpha$-tocopherol [184]. Other synthesised analogues include Vitamin E acetate, $\alpha$-tocopherylphosphate, and $\alpha$-tocopherylsuccinate [181].

(4) $\beta$-carotene: Besides tocopherols, carotenoids play an important role in the photoprotection of phototrophs by eliminating surplus energy as heat, directly scavenging reactive oxidants [148], including ${ }^{1} \mathrm{O}_{2}$ free radicals, and protecting cells from oxidative impairment by suppressing lipid peroxidation [149]. Their antioxidant property is attributed to their extended conjugated double bond system [186]. Low $\beta$-carotene levels have been shown to protect membrane lipids from peroxidative reactions [149].

(5) Gallic acid (GA): In plants, GA is a relatively ubiquitous [187] endogenous polyphenolic compound with several biological activities, including reacting with active oxidants, preventing their formation and accumulation [188]. GA occurs in the free or conjugate (as esterified hydrolysable tannins [56]) form in several plants [189]. Though polyphenols, such as quercetin [190], as well as GA [191], may act as prooxidants depending on concentration and condition [192], GA is primarily used as an antioxidant [193] due to its capacity to scavenge ROS, such as $\mathrm{H}_{2} \mathrm{O}_{2}$ [194].

\section{Seed Invigoration Treatments}

\subsection{A Brief History of Seed Pre-Hydration Treatment}

Seeds are continually faced with multiple challenges relating to production, postharvest storage, and subsequent quality. Moreover, in view of the effects of global warming as a symptom of climate change, different stress factors may cause poor seed performance in terms of reduced germination, uneven seedling emergence, poor seedling establishment, or destructive alteration of root cell architecture, leading to a substantial yield loss [195]. Hence, dating back to the ancient Greeks, concerted efforts towards the improvement of seed performance have led to the development of different pre-sowing treatment techniques that can augment germination and synchronise seedling emergence under different suboptimal growth conditions [196]. Seed pre-hydration was discovered by Theophrastus, Democritus (5th century B.C.), and Mago (4th-3rd century B.C) [197]. It was suggested that 
seed pre-hydration treatments in water or milk enhanced the germination of cucumber seeds (Theophrastus, D.H.P. Book VII, 1: 6). Democritus suggested steeping all seeds in some "roof tiles" plant extract before sowing (Plinius, N.H. Book XVIII, XLV: 159). Some other mentions include pre-hydrating almond seeds in a solution of honey or manure according to Carthaginian Mago (N.H. Book XVII, XI: 63), pre-hydrating pulses in "nitre" (Theophrastus, D.H.P. Book II, IV: 2), seed ripening of mistletoe in bird droppings (Plinius, N.H. Book XVI, XCII: 247), and pre-soaking B. oleracea seeds in houseleek extract to provide resistance to various insects (Plinius, N.H. Book XIX, LVIII: 180). The need to dry seeds artificially "to make them fertile" was also mentioned by Plinius (Plinius, N.H. Book XIX, XXXVI: 120) [197].

In the 16th century, Olivier de Serres described the steeping of grains (Hordeum, Secale and Triticum spp.) in manure solution for $24 \mathrm{~h}$ followed by drying back as a pre-sowing technique for enhanced seedling performance [196,198]. In the 19th century (1855), Charles Darwin [199] experimented with a seawater pre-hydration treatment and reported enhanced germination in treated cress and L. sativa seeds. May et al. [200] demonstrated that drying seeds for some time after hydration bestowed beneficial effects leading to increased germination rates under normal and adverse conditions. In 1963, Ells James presented the modern seed priming concept, pointing out the vital parameters of seed pre-hydration treatment and reporting that an increased rate of seedling emergence was observed in tomato seed exposed to the nutrient solution [196,198]. Heydecker [201] recognised the term seed "priming" as used by Malnassy [202], describing it as a seed pre-sowing treatment that can improve performance under suboptimal conditions [203]. Furthermore, Heydecker [201] described seed priming as a pre-hydration treatment in an osmotic solution that permits imbibition in the first germination phase before conversion of nutrient and radical protrusion. Such seeds are sometimes dried back ('hardening' [204]) to their initial moisture level and sown or stored [205]. In addition, the use of specific terms, such as halopriming (imbibing in salt solutions), and osmotic priming (imbibing in other osmotic solutions), were proposed [201] to specify the priming agent. The technique thus far is recognized and widely used to improve seed performance in the field of agriculture [206]. During pre-hydration treatment, the absorption of water is controlled to allow for the activation of pre-germinative metabolism without permitting radicle emergence by limiting the seed moisture content $[203,207]$. The resultant seedlings assume a physiological (primed) state which enables faster growth and/or better activation of plant defence responses [66,208].

\subsection{Seed Pre-Hydration and Pre-Germinative Metabolism}

In the 'primed state', the hydration-induced specific metabolic changes are responsible for the ensuing beneficial effects of seed pre-hydration treatments [196]. Upon seed imbibition, major cell functions and processes are activated, such as de novo proteins and nucleic acid biosynthesis, ATP formation, phospholipid and sterol accumulation, DNA repair and antioxidant system activation-the 'pre-germinative metabolism' [196]. Severe oxidative impairment of biomolecules such as lipids, nucleic acids, and proteins may occur in the early germination stages, during maturation on the mother plant, as well as in post-harvest storage, and under various stress conditions [54,78]. For seed vigour to be preserved and germination to be successful, embryonic DNA repair mechanisms must be well preserved. A good repair of impaired DNA allows for the resumption of cell cycle progression and DNA replication, while a defective repair system causes oxidative cell death $[54,209]$. DNA impairments in seed embryo are repaired during early imbibition and are essential for performance in terms of germination and storability [210]. Thus, DNA repair is a vital part of 'pre-germinative metabolism' triggered during imbibition and accompanied by unrestrained ROS activities [196] capable of causing mutation in the meristematic tissues of the embryo [211]. All major DNA repair pathways, such as baseand nucleotide-excision repair, are triggered at the early imbibition phase for the maintenance of genome integrity [209]. Efficient ligase-dependent re-joining of strand breaks is 
key to most DNA repairs, and DNA ligase VI, found only in plants, has been described as a major determining factor of seed quality and storability in Arabidopsis thaliana [210].

With regards to the regulatory roles of reactive oxidants in the germination of seeds, Møller et al. [100] suggested that comparatively long-lived oxidants, such as $\mathrm{H}_{2} \mathrm{O}_{2}$ take the signal to a distant target, whereas short-lived oxidants, such as $\mathrm{HO}^{\bullet}$, likely act near their production site; the product of oxidation (acting as a secondary messenger) then takes the signal to the target transcription factors. Besides signalling mediated by ROS, severe lesions to biomolecules can result from ROS activities. Though DNA impairments can be 'addressed' by certain repair functions, RNA is extremely sensitive to ROS-induced oxidative impairment owing to the lack of a specified mechanism of repair [212], while protein damage can be reversible (as in the oxidation of cysteine and methionine) and/or irreversible (as in carbonylation) [75,100,111].

Nevertheless, the enhanced activity of antioxidant (defence) enzymes such as APX, CAT, SOD, and GR allows for the control of ROS levels during imbibition $[213,214]$. The ROS scavenging antioxidant potential of the seed is critical for the enhancement of germination and stress tolerance [78]. In addition, gene expression profiling encoding antioxidant enzymes is a useful index of seed antioxidant response during germination. These safeguarding functions are triggered during pre-hydration treatments, thereby allowing seeds to undergo major metabolic and physiological pre-germinative phase changes up to the first cellular division, leading to improved germination and increased seedling vigour upon sowing [196].

\subsection{The Seed Priming Technology Overview}

The priming concept usually refers to several approaches towards seed invigoration, all involving controlled hydration of seeds [215]. The seed priming technique is used to improve the overall post-harvest performance of seed [216,217], including longevity (storability) $[218,219]$, and ability to withstand unfriendly environmental conditions $[66,220]$. Priming enhances seed germination in three phases (Figure 1) [40]: imbibition, germination, and growth [198]. During the first phase (imbibition), characterised by rapid water uptake owing to low seed water potential, respiratory activity and protein synthesis, through existing DNA and mRNA, are promoted. Phase II (germination) is a lag phase involving the initiation of various physiological functions relating to germination, including protein and mitochondria synthesis, degradation of stored food and reorganisation of cellular membranes, to support radicle protrusion and growth of the seedling, which commences in Phase III (growth phase) $[198,221]$. The key determinant of seed priming is the controlled uptake of water up to Phase II, prior to radicle emergence [198,221], which allows for vital physiological events, such as damaged DNA and mitochondria repair [40]. Priming duration can vary from less than $24 \mathrm{~h}$ [222] to days [223] or weeks [224], depending on cultivars, species, and seed lot [225]. Phase II is more sensitive to environmental factors than Phase III. Hence, primed seeds that have undergone Phase II may be able to germinate better than unprimed seeds under suboptimal conditions [198].

In many cases, primed seeds are dried back to a particular moisture level and stored [226] or sown by the conventional method $[227,228]$. Seed drying back is thought to confer a 'hardening' effect [229]. In the hardening technique, multiple (two to three soakings with drying back) cycles, are suggested to yield a better result, although one cycle is enough for most species $[226,230,231]$. Seed hardening induced by pre-sowing treatments is attributed to some cytoplasmic, physico-chemical changes, such as decreased lipophilic and increased hydrophilic colloids, greater protoplasmic elasticity and viscosity, increased hydration of colloids, increased bond water level, and increased protein coagulation temperature [231]. However, there have been reports of delayed germination and/or emergence in primed seeds that are dried back, relative to primed but not dried back seeds, owing to the extra time needed for rehydration, though other beneficial effects of priming are conserved [203,232]. Additionally, deterioration of seeds in storage has been reported when primed seeds were dried back in different species, such as Lycopersicon esculentum [233], Cichorium endivia [234], 
and L. sativa [235]. Tarquis and Bradford [236] stated that though pre-hydration treatments caused an increased germination rate, drying back predisposed L. sativa seeds to loss of storability. This effect varies depending on initial seed quality [203]. Thus, it has been suggested that the storage of primed seeds cannot extend beyond a few weeks as mechanisms for repair of impaired DNA become reduced [237]. In a study on Mimosa bimucronata, Brancalion et al. [238] added that priming benefits were partly lost in dried back seeds, recording lower performance in terms of percentage germination, seedling vigour, uniformity and germination speed index, and higher electrical conductivity relative to primed but not dried back seeds.

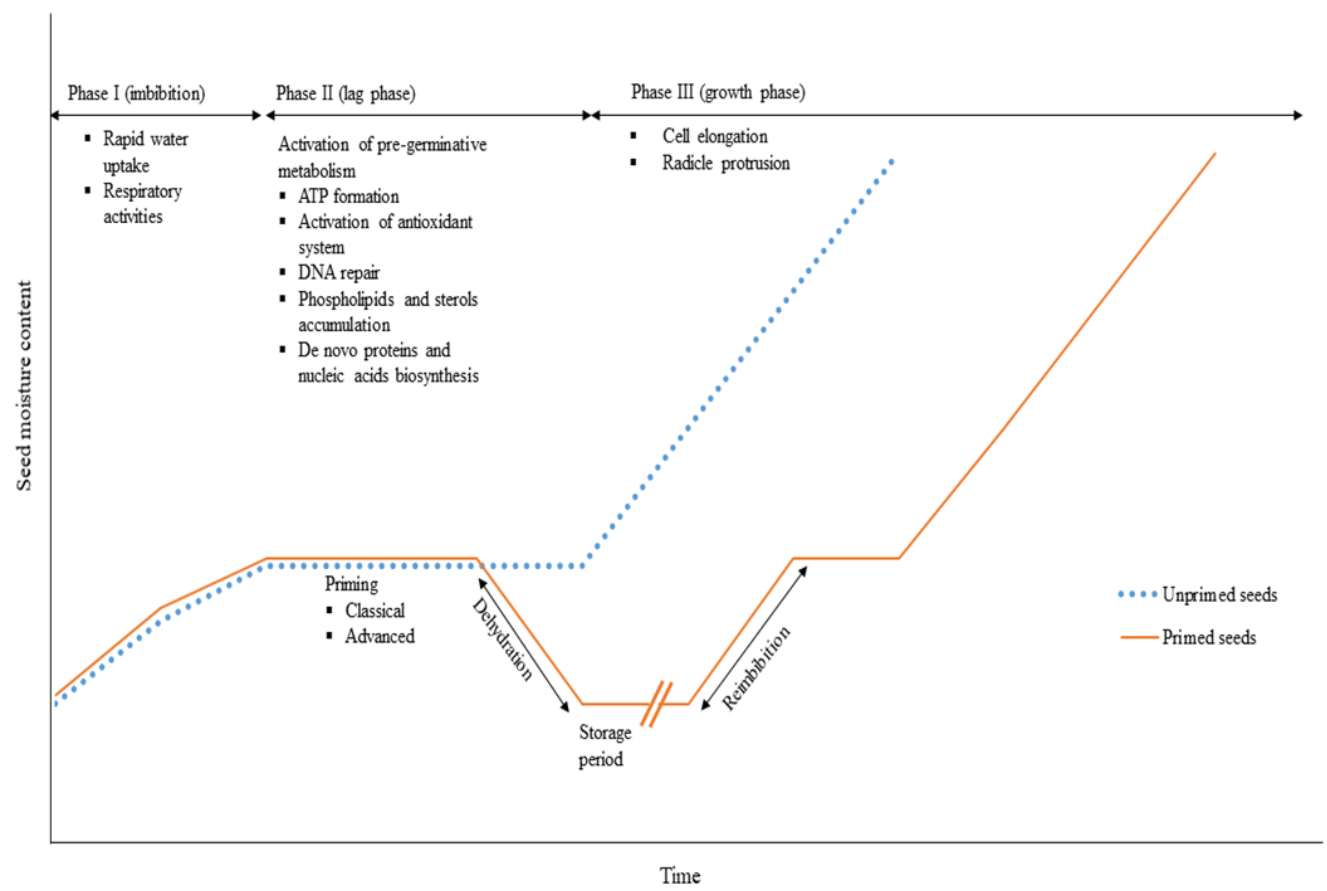

Figure 1. Imbibition curves showing the three phases of germination in unprimed and primed seeds.

\subsection{Seed Priming Methods}

Seed priming methods are generally divided into classical (hydropriming, osmopriming, redox priming, hormonal priming, cellular chemical priming, nutrient priming, and plant biostimulant biopriming [66,198,207]), and advanced (nanopriming [239], magnetopriming, irradiation with microwaves or ionising radiations and some other physical priming agents [240]) techniques, some of which are described below.

\subsubsection{Classical Seed Priming Techniques}

Hydropriming

Hydropriming is an age-old seed invigoration method popular with farmers as it is simple and economical. Hydropriming is of two types: drum-priming and on-farm priming [207]. Drum-priming involves seed hydration by water vapour generated from a gentle rotation of a drum at a particular temperature [204]. In on-farm priming, seeds are pre-soaked in water for a period before sowing [207,241]. The hydropriming technique is particularly useful under stressful conditions, such as high heat and salinity and water deficit stress, as seed hydration and water uptake efficiency in these conditions are enhanced [198]. However, maintaining optimum humidity and temperature is critical to preventing radicle protrusion, as hydropriming can allow for uncontrolled water uptake [242]. In contrast to unprimed (direct) sowing, the benefits of hydropriming have been demonstrated in several studies, including a 3-4 times increase in biomass allocation and seedling length of Cicer arietinum under drought stress conditions [243], rapid emergence and increased seedling vigour in rice seeds subjected to water-stress [227], and increased 
germination of three-years-stored seeds of napa cabbage (Brassica rapa) which correlated with decreased electrical leakage, as well as enhanced antioxidant enzymes (superoxide dismutase and peroxidase) activities, and soluble sugar level [244].

\section{Osmopriming}

In this pre-sowing treatment method, seeds are subjected to controlled hydration in an osmotic solution of low water potential generated from the addition of osmotica such as polyethylene glycol, sorbitol, glycerol, and mannitol to priming water $[66,207]$. The low water potential of the osmotic solution is a crucial factor enabling seeds to be partially hydrated for pre-germinative metabolism but inhibited protrusion of the radicle [245]. In addition, the use of various salt solutions (halopriming) has been widely reported, and their beneficial effects elucidated [246]. For instance, Singh et al. [247] osmoprimed Vigna unguiculata seeds with $\mathrm{KNO}_{3}$ solution and reported improved germination, plant height, and biomass accumulation compared with unprimed and hydroprimed seeds. Fatokun et al. [248] reported enhanced seedling emergence, photosynthetic and growth parameters of Pisum sativum and Cucurbita pepo seeds aged to $50 \%$ viability after priming with a mixture of $\mathrm{CaCl}_{2}$ and $\mathrm{MgCl}_{2}$ solutions relative to the unprimed seeds. Priming of $B$. oleracea seeds using varying levels $(1 \%, 2 \%$ and $3 \%)$ of inorganic salts, such as $\mathrm{KCl}$, $\mathrm{KH}_{2} \mathrm{PO}_{4}, \mathrm{KNO}_{3}, \mathrm{MgCl}_{2}, \mathrm{MgSO}_{4}$, and $\mathrm{NaCl}$, significantly increased germination, seedling vigour, biomass accumulation and reduced mean germination time [249]. Priming of artificially deteriorated Brassica napus seeds with $\mathrm{CaCl}_{2}$ promoted seedling vigour [250]. Carrozzi et al. [251] reported that priming with $\mathrm{MgSO}_{4}$ increased germination of L. sativa seeds stored for a year. Osmopriming is a low-cost priming option and allows for better water conservation [252].

\section{Redox Priming}

This seed invigoration method refers to priming with antioxidative compounds [66]. Plant cell redox state is key to the regulation of growth, development, and stress tolerance $[253,254]$. Plant redox status is disturbed in response to external stimuli, and the severity of disturbance is determined by the kind of stimulus, the amount, and the duration of, tissue exposure [66]. Maintaining an appropriate redox environment [255] is thought to help in minimising the severity of stress-induced damage [66]. During oxidative stress, antioxidants are well-known redox buffers capable of reacting with ROS and functioning as a metabolic interface that moderate the proper induction of acclimation responses or programmed cell death [256]. Among the compounds of major importance in the antioxidant pathway of plants, glutathione plays a significant role in the cellular redox signalling networks influencing growth, development, and defence $[66,178]$. Glutathione and tocopherol used as seed pre-hydration treatments resulted in increased seedling length in Helianthus annuus [257], gallic acid improved seedling vigour in B. oleracea [258], and trolox enhanced photosynthetic rate in L. sativa [259]. In addition, pre-hydration treatment of seeds with other antioxidant solutions has been reported to improve seed performance in several species. For instance, pre-hydration with ascorbic acid solution improved agronomic and biochemical vigour of Pisum sativum seeds [260] and improved germinability and tolerance to deterioration of Elymus sibiricus artificially aged for $48 \mathrm{~h}$ [261]. As mentioned by Afzal et al. [262], seed pre-hydration treatment with AA and tocopherol enhanced vigour and storability of H. annuus [263], maize, mustard [264] and Oryza sativa [265].

\section{Plant Biostimulant Priming}

Biostimulants are substances sourced from biological materials, e.g., microbial bioeffectors and extracts from plants and animals. They are diverse, ranging from single isolated compounds to complex matrices with various groups of biologically active constituents. The application of biostimulants to offset abiotic stress effects is well-established and represents one of the most promising techniques for attenuating stress impact in plants. It has attracted much interest both in research and commerce [266]. In addition to improving 
plant tolerance against several abiotic stressors, this eco-friendly innovation enhances nutrient use efficiency, plant growth, and crop productivity [267]. The stimulatory effects of plant biostimulants, such as smoke-water on Sceletium tortuosum seeds [268], karrikinolide on Lactuca sativa [269] and Aristolochia debilis [270] seeds, commercial brown seaweed extract $\left(\mathrm{Kelpak}^{\circledR}\right)$ on Abelmoschus esculentus [271] and Ceratotheca triloba [272] seeds, and yeast extract on Oryza sativa seeds [273], have been reported.

\subsubsection{Advanced Seed Priming Techniques}

Nanopriming

The use of nanomaterials in agriculture is somewhat recent relative to their application in biomedical and industrial sectors [239], and it is considered a promising approach that can transform food production and agriculture [274,275] to meet the demand for food security in view of the envisaged rise in world population [276,277]. Nanotechnology employs not more than $100 \mathrm{~nm}$ size of biocompatible nanoparticles [198], often synthesised with plant extracts of desirable phytochemical properties as the nanopriming agents (phytosynthesised nanoparticles) [239]. For example, Mahakham et al. [239] primed Oryza sativa seeds stored for three years using phytosynthesised silver particles obtained from silver nitrate $\left(\mathrm{AgNO}_{3}\right)$ solution mixed with Citrus hystrix leaves extract (as reducing and stabilising agents). They reported enhanced performance in terms of germination and seedling vigour. Further, they proposed the mechanisms of action of nanopriming-induced invigoration of seed to include nanopore formation for the enhancement of water uptake, optimising $\mathrm{ROS} /$ antioxidant systems in seeds, production of $\mathrm{HO} \bullet$ for loosening of the cell wall and weakening of endosperm to enhance seed germination as well as nanocatalyst-enhanced hydrolysis of starch. In another study, Sundaria et al. [277] demonstrated increased germination and shoot length in IITR26 and WL711 wheat (Triticum aestivum) genotypes, respectively, using iron oxide synthesised nanoparticles as a priming agent. Further, they demonstrated and proposed nanopriming for wheat grain biofortification with iron, which is a potential strategy for overcoming iron deficiency in humans.

\section{Seed Priming with Physical Agents}

Thus far, many studies have shown that plant metabolic and developmental processes are sensitive to magnetic fields [278-280]. Magnetic fields are now being used for the invigoration of seeds and enhancement of agricultural productivity $[207,281]$. Several beneficial effects of magnetopriming (priming with the magnetic field) have been documented in various studies for different plant species. For instance, Baby et al. [282] reported improved germination, vigour, seedling biomass, the performance index of chlorophyll a fluorescence, and reduced level of $\mathrm{O}_{2}{ }^{\bullet-}$ in leaves of Glycine max seeds primed with a static magnetic field. Besides increased germination and germination speed, field emergence, vigour and seedling biomass, other beneficial effects, such as improved membrane integrity and reduced electrolyte leakage, were reported in Helianthus annuus seeds subjected to magnetopriming [283]. Further, they ascribed high germination rates and vigour to magnetopriming-induced rise in $\alpha$-amylase, protease, and dehydrogenase activities.

Gamma radiation [240,284], UV radiation [285,286], X-rays [287,288], and microwaves [289,290] are some other commonly used physical priming agents [195,198].

\section{Conclusions}

There is little doubt that ageing-induced loss of crop seed vigour and viability is a serious threat to food security, particularly in countries where farmers are dependent on seed storage. Seed deterioration during long-term storage also poses a significant threat to germplasm conservation. Seed ageing, therefore, represents a challenge for the agri-food sector and seed industry, threatening the world's ability to meet global food demand. With increasing populations, especially in the developing nations, crop production losses owing to poor seed vigour have already resulted in market instability and enormous pressure on governments. This is expected to worsen when combined with the effects of climate 
change and human mass migrations. As a result, the United Nations (UN), in the 2030 Agenda for Sustainable Development, placed great emphasis on food security, improved nutrition, and sustainable agriculture [291]. Many resources have also been invested in research on seed storage, priming, and invigoration, to increase crop production.

In this regard, slowing down the deterioration of seeds and enhancing seed viability and vigour have become crucial for seed preservation, given the inevitability of seed viability loss even under enhanced storage conditions in gene banks. Seed treatments before storage for enhancing ageing resistance are useful and urgently needed, especially where long-term storage facilities are not available, or seeds are stored using poor and/or ageing infrastructure. Focused research involving the use of state-of-the-art techniques on seed invigoration will be useful in elucidating the mechanisms of ageing-induced loss of seed vigour and promising invigorative methods.

Author Contributions: Writing-original draft preparation, A.E.A.; writing—review and editing, T.L.A.; supervision, B.V., S. and N.W.P. All authors have read and agreed to the published version of the manuscript.

Funding: This work was supported by the National Research Foundation (Grant Holder Bursary), South Africa (grant number CPRR13092145823). The APC was partially funded by the University of KwaZulu-Natal, South Africa.

Conflicts of Interest: The authors declare no conflict of interest.

\section{References}

1. Hoban, S.M.; Hauffe, H.C.; Pérez-Espona, S.; Arntzen, J.W.; Bertorelle, G.; Bryja, J.; Frith, K.; Gaggiotti, O.E.; Galbusera, P.; Godoy, J.A.; et al. Bringing genetic diversity to the forefront of conservation policy and management. Conserv. Genet. Resour. 2013, 5, 593-598. [CrossRef]

2. Jacobsen, S.E.; Sørensen, M.; Pedersen, S.M.; Weiner, J. Feeding the world: Genetically modified crops versus agricultural biodiversity. Agron. Sustain. Dev. 2013, 33, 651-662. [CrossRef]

3. United Nations World Population Prospects 2019. Available online: https://population.un.org/wpp/Download/Standard/ Population/ (accessed on 14 October 2021).

4. Challinor, A.J.; Watson, J.; Lobell, D.B.; Howden, S.M.; Smith, D.R.; Chhetri, N. A meta-analysis of crop yield under climate change and adaptation. Nat. Clim. Chang. 2014, 4, 287-291. [CrossRef]

5. Khan, M.A.; Tahir, A.; Khurshid, N.; Husnain, M.I.u.; Ahmed, M.; Boughanmi, H. Economic effects of climate change-induced loss of agricultural production by 2050: A case study of Pakistan. Sustainability 2020, 12, 1216. [CrossRef]

6. Zinyengere, N.; Crespo, O.; Hachigonta, S. Crop response to climate change in southern Africa: A comprehensive review. Glob. Planet. Chang. 2013, 111, 118-126. [CrossRef]

7. Fahad, S.; Bajwa, A.A.; Nazir, U.; Anjum, S.A.; Farooq, A.; Zohaib, A.; Sadia, S.; Nasim, W.; Adkins, S.; Saud, S.; et al. Crop production under drought and heat stress: Plant responses and management options. Front. Plant Sci. 2017, 8, 1147. [CrossRef]

8. Conway, G.; Toenniessen, G. Feeding the world in the twenty-first century. Nature 1999, 402, C55-C58. [CrossRef]

9. Mann, C.C. Crop scientists seek a new revolution. Science 1999, 283, 310-314. [CrossRef]

10. Lipper, L.; Thornton, P.; Campbell, B.M.; Baedeker, T.; Braimoh, A.; Bwalya, M.; Caron, P.; Cattaneo, A.; Garrity, D.; Henry, K.; et al. Climate-smart agriculture for food security. Nat. Clim. Chang. 2014, 4, 1068-1072. [CrossRef]

11. Thornton, P.K.; Whitbread, A.; Baedeker, T.; Cairns, J.; Claessens, L.; Baethgen, W.; Bunn, C.; Friedmann, M.; Giller, K.E.; Herrero, M.; et al. A framework for priority-setting in climate smart agriculture research. Agric. Syst. 2018, 167, 161-175. [CrossRef]

12. Garnett, T.; Appleby, M.C.; Balmford, A.; Bateman, I.J.; Benton, T.G.; Bloomer, P.; Burlingame, B.; Dawkins, M.; Dolan, L.; Fraser, D.; et al. Sustainable intensification in agriculture: Premises and policies. Science 2013, 341, 33-34. [CrossRef]

13. Pretty, J.; Bharucha, Z.P. Sustainable intensification in agricultural systems. Ann. Bot. 2014, 114, 1571-1596. [CrossRef]

14. Cassman, K.G. Ecological intensification of cereal production systems: Yield potential, soil quality, and precision agriculture. Proc. Natl. Acad. Sci. USA 1999, 96, 5952-5959. [CrossRef]

15. FAO Seeds. Available online: http://www.fao.org/seeds/en/ (accessed on 31 August 2020).

16. Solberg, S.Ø.; Yndgaard, F.; Andreasen, C.; von Bothmer, R.; Loskutov, I.G.; Asdal, Å. Long-term storage and longevity of orthodox seeds: A systematic review. Front. Plant Sci. 2020, 11, 1007. [CrossRef]

17. Beal, W.J. The vitality of seeds buried in the soil. In Proceedings of the Society for the Promotion of Agricultural Science; 1911; pp. 21-23.

18. Beal, W.J. The viability of seeds. Bot. Gaz. 1905, 40, 140-143. [CrossRef]

19. Kivilaan, A.; Bandurski, R.S. The one hundred-year period for Dr. Beal's seed viability experiment. Am. J. Bot. 1981, 68, 1290-1292. [CrossRef] 
20. Steiner, A.M.; Ruckenbauer, P. Germination of 110-year-old cereal and weed seeds, the Vienna Sample of 1877 . Verification of effective ultra-dry storage at ambient temperature. Seed Sci. Res. 1995, 5, 195-199. [CrossRef]

21. Ruckenbauer, P. Keimfahiger Winterweizen aus dem Jahre 1877.-Beobachtungen und versuche (germinating winter wheat of the year 1877.-Observations and experiments). Die Bodenkultur. 1971, 22, 372-386.

22. Telewski, F.W.; Zeevaart, J.A.D. The 120-yr period for Dr. Beal's seed viability experiment. Am. J. Bot. 2002, 89, 1285-1288. [CrossRef] [PubMed]

23. Roberts, E.H.; Ellis, R.H. Water and seed survival. Ann. Bot. 1989, 63, 39. [CrossRef]

24. Vertucci, C.W.; Roos, E.E. Theoretical basis of protocols for seed storage. Plant Physiol. 1990, 94, 1019-1023. [CrossRef]

25. Ellis, R.H.; Hong, T.D.; Roberts, E.H. Seed moisture content, storage, viability and vigour. Seed Sci. Res. 1991, 1, $275-279$. [CrossRef]

26. Ellis, R.H.; Roberts, E.H. Improved equations for the prediction of seed longevity. Ann. Bot. 1980, 45, 13-30. [CrossRef]

27. Ibrahim, A.E.; Roberts, E.H. Viability of lettuce seeds: I. Survival in hermetic storage. J. Exp. Bot. 1983, 34, 620-630. [CrossRef]

28. Still, D.W. The development of seed quality in brassicas. Horttechnology 1999, 9, 335-340. [CrossRef]

29. Walters, C.; Towill, L. Seeds and pollen. In Agriculture Handbook. The Commercial Storage of Fruits, Vegetables, and Florist and Nursery Stocks; Gross, K.C., Wang, C.Y., Saltveit, M., Eds.; United States Department of Agriculture: Fort Collins, CO, USA, 2004; pp. 735-743; ISBN 3015046128.

30. Berjak, P.; Pammenter, N.W. Biotechnological aspects of non-orthodox seeds: An African perspective. S. Afr. J. Bot. 2004, 70, 102-108. [CrossRef]

31. Basra, S.M.A.; Ahmad, N.; Khan, M.M.; Iqbal, N.; Cheema, M.A. Assessment of cottonseed deterioration during accelerated ageing. Seed Sci. Technol. 2003, 31, 531-540. [CrossRef]

32. Poonguzhali, S. Improving vigour and viability of blackgram cv.co 6 [Vigna mungo (L) Hepper] through seed priming with inorganics. Legum. Res. Int. J. 2016, 39, 820-829. [CrossRef]

33. Walters, C.; Wheeler, L.M.; Grotenhuis, J.M. Longevity of seeds stored in a genebank: Species characteristics. Seed Sci. Res. 2005, 15, 1-20. [CrossRef]

34. Chmielarz, P. Cryopreservation of dormant European ash (Fraxinus excelsior) orthodox seeds. Tree Physiol. 2009, 29, 1279-1285. [CrossRef] [PubMed]

35. Shaban, M. Review on physiological aspects of seed deterioration. Int. J. Agric. Crop Sci. 2013, 6, 627-631.

36. Chmielarz, P. Cryopreservation of orthodox seeds of Alnus glutinosa. CryoLetters 2010, 31, 139-146. [PubMed]

37. Walters, C.; Wheeler, L.; Stanwood, P.C. Longevity of cryogenically stored seeds. Cryobiology 2004, 48, 229-244. [CrossRef]

38. Brown, R. Physiology of seed germination. In Differenzierung und Entwicklung/Differentiation and Development. Handbuch der Pflanzenphysiologie/Encyclopedia of Plant Physiology; Lang, A., Ed.; Springer: Berlin/Heidelberg, Germany, 1965; Volume 15, pp. 2541-2555.

39. Bewley, J.D.; Black, M. Seeds: Physiology of Development and Germination, 2nd ed.; Springer US: Boston, MA, USA, 1994; ISBN 978-0-306-44748-8.

40. Bewley, J.D. Seed germination and dormancy. Plant Cell 1997, 9, 1055-1066. [CrossRef] [PubMed]

41. Welbaum, G.E.; Bradford, K.J.; Yim, K.-O.; Booth, D.T.; Oluoch, M.O. Biophysical, physiological and biochemical processes regulating seed germination. Seed Sci. Res. 1998, 8, 161-172. [CrossRef]

42. Pritchard, S.L.; Charlton, W.L.; Baker, A.; Graham, I.A. Germination and storage reserve mobilization are regulated independently in Arabidopsis. Plant J. 2002, 31, 639-647. [CrossRef]

43. Demidchik, V. Reactive oxygen species and their role in plant oxidative stress. In Plant Stress Physiology; Shabala, S., Ed.; CABI: Wallingford, UK, 2017; pp. 64-96. ISBN 9781780647296.

44. Sharma, P.; Dubey, R.S. Drought induces oxidative stress and enhances the activities of antioxidant enzymes in growing rice seedlings. Plant Growth Regul. 2005, 46, 209-221. [CrossRef]

45. Demidchik, V. Mechanisms of oxidative stress in plants: From classical chemistry to cell biology. Environ. Exp. Bot. 2015, 109, 212-228. [CrossRef]

46. Mittler, R. Oxidative stress, antioxidants and stress tolerance. Trends Plant Sci. 2002, 7, 405-410. [CrossRef]

47. Demidchik, V. Reactive oxygen species, oxidative stress and plant ion channels. In Ion Channels and Plant Stress Responses. Signaling and Communication in Plants; Signaling and Communication in Plants; Demidchik, V., Maathuis, F., Eds.; Springer: Berlin/Heidelberg, Germany, 2010; pp. 207-232.

48. Zhu, J.; Gong, Z.; Zhang, C.; Song, C.P.; Damsz, B.; Inan, G.; Koiwa, H.; Zhu, J.K.; Hasegawa, P.M.; Bressan, R.A. OSM1/SYP61: A syntaxin protein in Arabidopsis controls abscisic acid-mediated and non-abscisic acid-mediated responses to abiotic stress. Plant Cell 2002, 14, 3009-3028. [CrossRef]

49. Hasegawa, P.M.; Bressan, R.A.; Zhu, J.-K.; Bohnert, H.J. Plant cellular and molecular responses to high salinity. Annu. Rev. Plant Physiol. Plant Mol. Biol. 2000, 51, 463-499. [CrossRef]

50. Varghese, B.; Sershen; Berjak, P.; Varghese, D.; Pammenter, N.W. Differential drying rates of recalcitrant Trichilia dregeana embryonic axes: A study of survival and oxidative stress metabolism. Physiol. Plant. 2011, 142, 326-338. [CrossRef] [PubMed]

51. Karpinski, S.; Escobar, C.; Karpinska, B.; Creissen, G.; Mullineaux, P.M. Photosynthetic electron transport regulates the expression of cytosolic ascorbate peroxidase genes in Arabidopsis during excess light stress. Plant Cell 1997, 9, 627-640. [CrossRef] [PubMed]

52. Ali, M.B.; Hahn, E.J.; Paek, K.Y. Effects of temperature on oxidative stress defense systems, lipid peroxidation and lipoxygenase activity in Phalaenopsis. Plant Physiol. Biochem. 2005, 43, 213-223. [CrossRef] 
53. Møller, I.M. Plant mitochondria and oxidative stress: Electron transport, NADPH turnover, and metabolism of reactive oxygen species. Annu. Rev. Plant Physiol. Plant Mol. Biol. 2001, 52, 561-591. [CrossRef]

54. Kranner, I.; Minibayeva, F.V.; Beckett, R.P.; Seal, C.E. What is stress? Concepts, definitions and applications in seed science. New Phytol. 2010, 188, 655-673. [CrossRef]

55. Hendry, G.A.F. Oxygen, free radical processes and seed longevity. Seed Sci. Res. 1993, 3, 141-153. [CrossRef]

56. Taiz, L.; Zeiger, E. Plant Physiology, 5th ed.; Sinauer Assosiates Inc.: Sunderland, MA, USA, 2010 ; ISBN 9780878938667.

57. Saha, H.; Mitra, M.; Deepa Sankar, P. Oxidative stress and approaches to enhance abiotic stress tolerance in plants. Res. J. Pharm. Biol. Chem. Sci. 2014, 5, 724-734.

58. Bartosz, G. Oxidative stress in plants. Acta Physiol. Plant. 1997, 19, 47-64. [CrossRef]

59. Mirdad, Z.; Powell, A.A.; Matthews, S. Prediction of germination in artificially aged seeds of Brassica spp. using the bulk conductivity test. Seed Sci. Technol. 2006, 34, 273-286. [CrossRef]

60. Boniecka, J.; Kotowicz, K.; Skrzypek, E.; Dziurka, K.; Rewers, M.; Jedrzejczyk, I.; Wilmowicz, E.; Berdychowska, J.; Dabrowska, G.B. Potential biochemical, genetic and molecular markers of deterioration advancement in seeds of oilseed rape (Brassica napus L.). Ind. Crops Prod. 2019, 130, 478-490. [CrossRef]

61. Golovina, E.A.; Wolkers, W.F.; Hoekstra, F.A. Behaviour of membranes and proteins during natural seed ageing. In Basic and Applied Aspects of Seed Biology: Proceedings of the Fifth International Workshop on Seeds, Reading, 1995; Ellis, R.H., Black, M., Murdoch, A.J., Hong, T.D., Eds.; Springer: Dordrecht, The Netherlands, 1997; pp. 787-796. ISBN 978-94-011-5716-2.

62. Golovina, E.A.; Wolkers, W.F.; Hoekstra, F.A. Long-term stability of protein secondary structure in dry seeds. Comp. Biochem. Physiol. Part A Physiol. 1997, 117, 343-348. [CrossRef]

63. Smith, M.T. Membrane Changes and Lipid Peroxidation during Ageing in Seeds of Lactuca sativa L. Ph.D. Thesis, University of Natal, Durban, South Africa, 1986.

64. Mira, S.; González-Benito, M.E.; Hill, L.M.; Walters, C. Characterization of volatile production during storage of lettuce (Lactuca sativa) seed. J. Exp. Bot. 2010, 61, 3915-3924. [CrossRef]

65. Mittler, R. Abiotic stress, the field environment and stress combination. Trends Plant Sci. 2006, 11, 15-19. [CrossRef]

66. Jisha, K.C.; Vijayakumari, K.; Puthur, J.T. Seed priming for abiotic stress tolerance: An overview. Acta Physiol. Plant. 2013, 35, 1381-1396. [CrossRef]

67. Ghosh, D.; Xu, J. Abiotic stress responses in plant roots: A proteomics perspective. Front. Plant Sci. 2014, 5, 6. [CrossRef] [PubMed]

68. Gouveia, G.C.C.; da Silva Binotti, F.F.; Costa, E. Priming effect on the physiological potential of maize seeds under abiotic stress1. Pesqui. Agropecuária Trop. 2017, 47, 328-335. [CrossRef]

69. Kurek, K.; Plitta-Michalak, B.; Ratajczak, E. Reactive oxygen species as potential drivers of the seed aging process. Plants $2019,8,174$. [CrossRef]

70. Zhao, L.; Wang, S.; Fu, Y.B.; Wang, H. Arabidopsis seed stored mRNAs are degraded constantly over aging time, as revealed by new quantification methods. Front. Plant Sci. 2020, 10, 1764. [CrossRef]

71. Saed-Moucheshi, A.; Shekoofa, A.; Pessarakli, M. Reactive oxygen species (ROS) generation and detoxifying in plants. J. Plant Nutr. 2014, 37, 1573-1585. [CrossRef]

72. Mittler, R. ROS are good. Trends Plant Sci. 2017, 22, 11-19. [CrossRef]

73. Kibinza, S.; Vinel, D.; Côme, D.; Bailly, C.; Corbineau, F. Sunflower seed deterioration as related to moisture content during ageing, energy metabolism and active oxygen species scavenging. Physiol. Plant. 2006, 128, 496-506. [CrossRef]

74. Mira, S.; Estrelles, E.; González-Benito, M.E.; Corbineau, F. Biochemical changes induced in seeds of Brassicaceae wild species during ageing. Acta Physiol. Plant. 2011, 33, 1803-1809. [CrossRef]

75. Anjum, N.A.; Sofo, A.; Scopa, A.; Roychoudhury, A.; Gill, S.S.; Iqbal, M.; Lukatkin, A.S.; Pereira, E.; Duarte, A.C.; Ahmad, I. Lipids and proteins-Major targets of oxidative modifications in abiotic stressed plants. Environ. Sci. Pollut. Res. 2015, 22, 4099-4121. [CrossRef]

76. Farmer, E.E.; Mueller, M.J. ROS-mediated lipid peroxidation and RES-activated signaling. Annu. Rev. Plant Biol. 2013, 64, 429-450. [CrossRef]

77. Feng, J.; Shen, Y.; Shi, F.; Li, C. Changes in seed germination ability, lipid peroxidation and antioxidant enzyme activities of Ginkgo biloba seed during desiccation. Forests 2017, 8, 286. [CrossRef]

78. Sahu, B.; Sahu, A.K.; Thomas, V.; Naithani, S.C. Reactive oxygen species, lipid peroxidation, protein oxidation and antioxidative enzymes in dehydrating Karanj (Pongamia pinnata) seeds during storage. S. Afr. J. Bot. 2017, 112, 383-390. [CrossRef]

79. Al-maskri, A.; Kharr, M.M.; Ai-mantheriand, O.; Al-habs, K. Effect of accelerated aging on lipid peroxidation, leakage and seedling vigor (RGR) in cucumber (Cucumis sativus L.) seeds. Park. J Agric. Sci. 2002, 39, 330-337.

80. Alexeyev, M.F. Is there more to aging than mitochondrial DNA and reactive oxygen species? FEBS J. 2009, $276,5768-5787$. [CrossRef]

81. Oenel, A.; Fekete, A.; Krischke, M.; Faul, S.C.; Gresser, G.; Havaux, M.; Mueller, M.J.; Berger, S. Enzymatic and non-enzymatic mechanisms contribute to lipid oxidation during seed aging. Plant Cell Physiol. 2017, 58, 925-933. [CrossRef] [PubMed]

82. Gutteridge, J.M.C. Lipid peroxidation and antioxidants as biomarkers of tissue damage. Clin. Chem. 1995, 41, 1819-1828. [CrossRef] 
83. Catalá, A. An overview of lipid peroxidation with emphasis in outer segments of photoreceptors and the chemiluminescence assay. Int. J. Biochem. Cell Biol. 2006, 38, 1482-1495. [CrossRef]

84. Porter, N.A. Chemistry of lipid peroxidation. In Methods in Enzymology; Packer, L., Ed.; Academic Press: Cambridge, MA, USA, 1984; Volume 105, pp. 273-282. ISBN 012182005X.

85. Halliwell, B.; Chirico, S. Lipid peroxidation: Its mechanism, measurement, and significance. Am. J. Clin. Nutr. 1993, 57, 715S-725S. [CrossRef]

86. Krieger-Liszkay, A.; Fufezan, C.; Trebst, A. Singlet oxygen production in photosystem II and related protection mechanism. Photosynth. Res. 2008, 98, 551-564. [CrossRef]

87. Przybyla, D.; Göbel, C.; Imboden, A.; Hamberg, M.; Feussner, I.; Apel, K. Enzymatic, but not non-enzymatic, 1O2-mediated peroxidation of polyunsaturated fatty acids forms part of the EXECUTER1-dependent stress response program in the flu mutant of Arabidopsis thaliana. Plant J. 2008, 54, 236-248. [CrossRef] [PubMed]

88. Nowicka, B.; Gruszka, J.; Kruk, J. Function of plastochromanol and other biological prenyllipids in the inhibition of lipid peroxidation-A comparative study in model systems. Biochim. Biophys. Acta-Biomembr. 2013, 1828, 233-240. [CrossRef] [PubMed]

89. Esterbauer, H.; Schaur, R.J.; Zollner, H. Chemistry and biochemistry of 4-hydroxynonenal, malonaldehyde and related aldehydes. Free Radic. Biol. Med. 1991, 11, 81-128. [CrossRef]

90. Bentinger, M.; Brismar, K.; Dallner, G. The antioxidant role of coenzyme Q. Mitochondrion 2007, 7, S41-S50. [CrossRef]

91. Kristal, B.S.; Park, B.K.; Yu, B.P. 4-Hydroxyhexenal is a potent inducer of the mitochondrial permeability transition. J. Biol. Chem. 1996, 271, 6033-6038. [CrossRef]

92. Yin, L.; Mano, J.; Wang, S.; Tsuji, W.; Tanaka, K. The involvement of lipid peroxide-derived aldehydes in aluminum toxicity of tobacco roots. Plant Physiol. 2010, 152, 1406-1417. [CrossRef]

93. Feussner, I.; Wasternack, C. The lipoxygenase pathway. Annu. Rev. Plant Biol. 2002, 53, 275-297. [CrossRef]

94. Andreou, A.; Feussner, I. Lipoxygenases-Structure and reaction mechanism. Phytochemistry 2009, 70, 1504-1510. [CrossRef] [PubMed]

95. Li, J.; Zhang, Y.; Yu, Z.; Wang, Y.; Yang, Y.; Liu, Z.; Jiang, J.; Song, M.; Wu, Y. Superior storage stability in low lipoxygenase maize varieties. J. Stored Prod. Res. 2007, 43, 530-534. [CrossRef]

96. Gayen, D.; Ali, N.; Ganguly, M.; Paul, S.; Datta, K.; Datta, S.K. RNAi mediated silencing of lipoxygenase gene to maintain rice grain quality and viability during storage. Plant Cell. Tissue Organ Cult. 2014, 118, 229-243. [CrossRef]

97. Song, M.; Wu, Y.; Zhang, Y.; Liu, B.M.; Jiang, J.Y.; Xu, X.; Yu, Z.L. Mutation of rice (Oryza sativa L.) LOX-1/2 near-isogenic lines with ion beam implantation and study of their storability. Nucl. Instrum. Methods Phys. Res. B 2007, 265, 495-500. [CrossRef]

98. Li, Z.; Gao, Y.; Lin, C.; Pan, R.; Ma, W.; Zheng, Y.; Guan, Y.; Hu, J. Suppression of LOX activity enhanced seed vigour and longevity of tobacco (Nicotiana tabacum L.) seeds during storage. Conserv. Physiol. 2018, 6, coy047. [CrossRef]

99. Davies, M.J. Singlet oxygen-mediated damage to proteins and its consequences. Biochem. Biophys. Res. Commun. 2003, 305, 761-770. [CrossRef]

100. Møller, I.M.; Jensen, P.E.; Hansson, A. Oxidative modifications to cellular components in plants. Annu. Rev. Plant Biol. 2007, 58, 459-481. [CrossRef]

101. Hawkins, C.L.; Morgan, P.E.; Davies, M.J. Quantification of protein modification by oxidants. Free Radic. Biol. Med. 2009, 46, 965-988. [CrossRef]

102. Rinalducci, S.; Murgiano, L.; Zolla, L. Redox proteomics: Basic principles and future perspectives for the detection of protein oxidation in plants. J. Exp. Bot. 2008, 59, 3781-3801. [CrossRef] [PubMed]

103. Starke-Reed, P.E.; Oliver, C.N. Protein oxidation and proteolysis during aging and oxidative stress. Arch. Biochem. Biophys. 1989, 275, 559-567. [CrossRef]

104. Stadtman, E. Protein oxidation and aging. Science 1992, 257, 1220-1224. [CrossRef]

105. Oracz, K.; Bouteau, H.E.M.; Farrant, J.M.; Cooper, K.; Belghazi, M.; Job, C.; Job, D.; Corbineau, F.; Bailly, C. ROS production and protein oxidation as a novel mechanism for seed dormancy alleviation. Plant J. 2007, 50, 452-465. [CrossRef] [PubMed]

106. Kumar, A.; Prasad, A.; Sedlářová, M.; Pospíšil, P. Organic radical imaging in plants: Focus on protein radicals. Free Radic. Biol. Med. 2019, 130, 568-575. [CrossRef]

107. Johansson, E.; Olsson, O.; Nyström, T. Progression and specificity of protein oxidation in the life cycle of Arabidopsis thaliana. J. Biol. Chem. 2004, 279, 22204-22208. [CrossRef] [PubMed]

108. Avery, S.V. Molecular targets of oxidative stress. Biochem. J. 2011, 434, 201-210. [CrossRef] [PubMed]

109. Medicherla, B.; Goldberg, A.L. Heat shock and oxygen radicals stimulate ubiquitin-dependent degradation mainly of newly synthesized proteins. J. Cell Biol. 2008, 182, 663-673. [CrossRef]

110. Dalle-Donne, I.; Rossi, R.; Giustarini, D.; Milzani, A.; Colombo, R. Protein carbonyl groups as biomarkers of oxidative stress. Clin Chim. Acta 2003, 329, 23-38. [CrossRef]

111. Ghezzi, P.; Bonetto, V. Redox proteomics: Identification of oxidatively modified proteins. Proteomics 2003, 3, 1145-1153. [CrossRef]

112. Shacter, E. Quantification and significance of protein oxidation in biological samples. Drug Metab. Rev. 2000, 32, 307-326. [CrossRef] [PubMed]

113. Hawkins, C.L.; Davies, M.J. Detection, identification, and quantification of oxidative protein modifications. J. Biol. Chem. 2019, 294, 19683-19708. [CrossRef] [PubMed] 
114. Isbell, H.S.; Frush, H.L.; Martin, E.T. Reactions of carbohydrates with hydroperoxides. Carbohydr. Res. 1973, $26,287-295$. [CrossRef]

115. Headlam, H.A.; Davies, M.J. Markers of protein oxidation: Different oxidants give rise to variable yields of bound and released carbonyl products. Free Radic. Biol. Med. 2004, 36, 1175-1184. [CrossRef] [PubMed]

116. Moran, J.F.; Becana, M.; Iturbe-Ormaetxe, I.; Frechilla, S.; Klucas, R.V.; Aparicio-Tejo, P. Drought induces oxidative stress in pea plants. Planta 1994, 194, 346-352. [CrossRef]

117. Morscher, F.; Kranner, I.; Arc, E.; Bailly, C.; Roach, T. Glutathione redox state, tocochromanols, fatty acids, antioxidant enzymes and protein carbonylation in sunflower seed embryos associated with after-ripening and ageing. Ann. Bot. 2015, 116, 669-678. [CrossRef] [PubMed]

118. Milkovska-Stamenova, S.; Schmidt, R.; Frolov, A.; Birkemeyer, C. GC-MS Method for the quantitation of carbohydrate intermediates in glycation systems. J. Agric. Food Chem. 2015, 63, 5911-5919. [CrossRef]

119. Shumilina, J.; Kusnetsova, A.; Tsarev, A.; Janse van Rensburg, H.C.; Medvedev, S.; Demidchik, V.; Van den Ende, W.; Frolov, A. Glycation of plant proteins: Regulatory roles and interplay with sugar signalling? Int. J. Mol. Sci. 2019, 20, 2366. [CrossRef]

120. Lounifi, I.; Arc, E.; Molassiotis, A.; Job, D.; Rajjou, L.; Tanou, G. Interplay between protein carbonylation and nitrosylation in plants. Proteomics 2013, 13, 568-578. [CrossRef]

121. Roychoudhury, A.; Basu, S.; Sengupta, D.N. Amelioration of salinity stress by exogenously applied spermidine or spermine in three varieties of indica rice differing in their level of salt tolerance. J. Plant Physiol. 2011, 168, 317-328. [CrossRef]

122. Tanou, G.; Filippou, P.; Belghazi, M.; Job, D.; Diamantidis, G.; Fotopoulos, V.; Molassiotis, A. Oxidative and nitrosative-based signaling and associated post-translational modifications orchestrate the acclimation of citrus plants to salinity stress. Plant $\mathrm{J}$. 2012, 72, 585-599. [CrossRef]

123. Pyngrope, S.; Bhoomika, K.; Dubey, R.S. Oxidative stress, protein carbonylation, proteolysis and antioxidative defense system as a model for depicting water deficit tolerance in Indica rice seedlings. Plant Growth Regul. 2013, 69, 149-165. [CrossRef]

124. Rellán-Álvarez, R.; Ortega-Villasante, C.; Álvarez-Fernández, A.; del Campo, F.F.; Hernández, L.E. Stress responses of Zea mays to cadmium and mercury. Plant Soil 2006, 279, 41-50. [CrossRef]

125. Song, H.; Xu, X.; Wang, H.; Tao, Y. Protein carbonylation in barley seedling roots caused by aluminum and proton toxicity is suppressed by salicylic acid. Russ. J. Plant Physiol. 2011, 58, 653-659. [CrossRef]

126. Xu, X.; Qin, G.; Tian, S. Effect of microbial biocontrol agents on alleviating oxidative damage of peach fruit subjected to fungal pathogen. Int. J. Food Microbiol. 2008, 126, 153-158. [CrossRef] [PubMed]

127. Sundaram, S.; Rathinasabapathi, B. Transgenic expression of fern Pteris vittata glutaredoxin PvGrx 5 in Arabidopsis thaliana increases plant tolerance to high temperature stress and reduces oxidative damage to proteins. Planta 2010, 231, 361-369. [CrossRef] [PubMed]

128. Rajjou, L.; Lovigny, Y.; Groot, S.P.C.; Belghazi, M.; Job, C.; Job, D. Proteome-wide characterization of seed aging in Arabidopsis: A comparison between artificial and natural aging protocols. Plant Physiol. 2008, 148, 620-641. [CrossRef]

129. Yin, G.; Xin, X.; Fu, S.; An, M.; Wu, S.; Chen, X.; Zhang, J.; He, J.; Whelan, J.; Lu, X. Proteomic and carbonylation profile analysis at the critical node of seed ageing in Oryza sativa. Sci. Rep. 2017, 7, 40611. [CrossRef]

130. Smirnoff, N.; Cumbes, Q.J. Hydroxyl radical scavenging activity of compatible solutes. Phytochemistry 1989, 28, 1057-1060. [CrossRef]

131. Miller, A.R. Oxidation of cell wall polysaccharides by hydrogen peroxide: A potential mechanism for cell wall breakdown in plants. Biochem. Biophys. Res. Commun. 1986, 141, 238-244. [CrossRef]

132. Schopfer, P.; Liszkay, A.; Bechtold, M.; Frahry, G.; Wagner, A. Evidence that hydroxyl radicals mediate auxin-induced extension growth. Planta 2002, 214, 821-828. [CrossRef]

133. Fry, S.C.; Miller, J.G.; Dumville, J.C. A proposed role for copper ions in cell wall loosening. In Progress in Plant Nutrition: Plenary Lectures of the XIV International Plant Nutrition Colloquium; Springer: Dordrecht, The Netherlands, 2002; Volume 247, pp. 57-67.

134. Connolly, E.L.; Guerinot, M. Lou Iron stress in plants. Genome Biol. 2002, 3, 1-4. [CrossRef]

135. Couée, I.; Sulmon, C.; Gouesbet, G.; El Amrani, A. Involvement of soluble sugars in reactive oxygen species balance and responses to oxidative stress in plants. J. Exp. Bot. 2006, 57, 449-459. [CrossRef] [PubMed]

136. Jouve, L.; Hoffmann, L.; Hausman, J.F. Polyamine, carbohydrate, and proline content changes during salt stress exposure of aspen (Populus tremula L.): Involvement of oxidation and osmoregulation metabolism. Plant Biol. 2004, 6, 74-80. [CrossRef]

137. Patel, T.K.; Williamson, J.D. Mannitol in plants, fungi, and plant-fungal interactions. Trends Plant Sci. 2016, 21, 486-497. [CrossRef] [PubMed]

138. El-Maarouf-Bouteau, H.; Mazuy, C.; Corbineau, F.; Bailly, C. DNA alteration and programmed cell death during ageing of sunflower seed. J. Exp. Bot. 2011, 62, 5003-5011. [CrossRef]

139. Roldán-Arjona, T.; Ariza, R.R. Repair and tolerance of oxidative DNA damage in plants. Mutat. Res. 2009, 681, 169-179. [CrossRef] [PubMed]

140. Jeong, Y.-C. Pyrimido[1,2-a]-purin-10(3H)-one, M1G, is less prone to artifact than base oxidation. Nucleic Acids Res. 2005, 33, 6426-6434. [CrossRef]

141. Britt, A.B. DNA damage and repair in plants. Annu. Rev. Plant Physiol. Plant Mol. Biol. 1996, 47, 75-100. [CrossRef]

142. Larsen, N.B.; Rasmussen, M.; Rasmussen, L.J. Nuclear and mitochondrial DNA repair: Similar pathways? Mitochondrion 2005, 5 , 89-108. [CrossRef] 
143. Yoshiyama, K.; Sakaguchi, K.; Kimura, S. DNA damage response in plants: Conserved and variable response compared to animals. Biology 2013, 2, 1338-1356. [CrossRef]

144. Vanderauwera, S.; Suzuki, N.; Miller, G.; van de Cotte, B.; Morsa, S.; Ravanat, J.-L.; Hegie, A.; Triantaphylides, C.; Shulaev, V.; Van Montagu, M.C.E.; et al. Extranuclear protection of chromosomal DNA from oxidative stress. Proc. Natl. Acad. Sci. USA 2011, 108, 1711-1716. [CrossRef] [PubMed]

145. Mullarky, E.; Cantley, L.C. Diverting glycolysis to combat oxidative stress. In Innovative Medicine; Nakao, K., Minato, N., Uemoto, S., Eds.; Springer: Tokyo, Japan, 2015; pp. 3-23.

146. Dat, J.; Vandenabeele, S.; Vranová, E.; Van Montagu, M.; Inzé, D.; Van Breusegem, F. Dual action of the active oxygen species during plant stress responses. Cell. Mol. Life Sci. 2000, 57, 779-795. [CrossRef] [PubMed]

147. Perl-Treves, R.; Perl, A. Oxidative stress: An introduction. In Oxidative Stress in Plants; Inzé, D., Van Montagu, M., Eds.; Taylor \& Francis: London, UK, 2002; pp. 1-32.

148. Gill, S.S.; Tuteja, N. Reactive oxygen species and antioxidant machinery in abiotic stress tolerance in crop plants. Plant Physiol. Biochem. 2010, 48, 909-930. [CrossRef]

149. Govindaraj, M.; Masilamani, P.; Albert, V.A.; Bhaskaran, M. Role of antioxidant in seed quality-A review. Agric. Rev. 2017, 38, 180-190. [CrossRef]

150. Fridovich, I. Superoxide radical and superoxide dismutases. In Autoxidation in Food and Biological Systems; Springer: Boston, MA, USA, 1981; Volume 110, pp. 250-272.

151. del Río, L.A.; Corpas, F.J.; López-Huertas, E.; Palma, J.M. Plant superoxide dismutases: Function under abiotic stress conditions. In Antioxidants and Antioxidant Enzymes in Higher Plants; Springer International Publishing: Cham, Switzerland, 2018; pp. 1-26. ISBN 9783319750880.

152. Anjum, N.A.; Sharma, P.; Gill, S.S.; Hasanuzzaman, M.; Khan, E.A.; Kachhap, K.; Mohamed, A.A.; Thangavel, P.; Devi, G.D.; Vasudhevan, P.; et al. Catalase and ascorbate peroxidase-Representative $\mathrm{H}_{2} \mathrm{O}_{2}$-detoxifying heme enzymes in plants. Environ. Sci. Pollut. Res. 2016, 23, 19002-19029. [CrossRef]

153. Shugaev, A.G.; Lashtabega, D.A.; Shugaeva, N.A.; Vyskrebentseva, E.I. Activities of antioxidant enzymes in mitochondria of growing and dormant sugar beet roots. Russ. J. Plant Physiol. 2011, 58, 387-393. [CrossRef]

154. Bailly, C.; Benamar, A.; Corbineau, F.; Côme, D. Changes in malondialdehyde content and in superoxide dismutase, catalase and glutathione reductase activities in sunflower seeds as related to deterioration during accelerated aging. Physiol. Plant. 1996, 97, 104-110. [CrossRef]

155. Kibinza, S.; Bazin, J.; Bailly, C.; Farrant, J.M.; Corbineau, F.; El-Maarouf-Bouteau, H. Catalase is a key enzyme in seed recovery from ageing during priming. Plant Sci. 2011, 181, 309-315. [CrossRef]

156. Liu, Y.; Yao, Y.; Hu, X.; Xing, S.; Xu, L. Cloning and allelic variation of two novel catalase genes (SoCAT-1 and SsCAT-1) in Saccharum officinarum L. and Saccharum spontaneum L. Biotechnol. Biotechnol. Equip. 2015, 29, 431-440. [CrossRef]

157. Yoshimura, K.; Miyao, K.; Gaber, A.; Takeda, T.; Kanaboshi, H.; Miyasaka, H.; Shigeoka, S. Enhancement of stress tolerance in transgenic tobacco plants overexpressing Chlamydomonas glutathione peroxidase in chloroplasts or cytosol. Plant J. 2004, 37, 21-33. [CrossRef]

158. Yousuf, P.Y.; Hakeem, K.U.R.; Chandna, R.; Ahmad, P. Role of glutathione reductase in plant abiotic stress. In Abiotic Stress Responses in Plants; Ahmad, P., Prasad, M.N.V., Eds.; Springer: New York, NY, USA, 2012; pp. 149-158. ISBN 978-1-4614-0633-4.

159. Ozyigit, I.I.; Filiz, E.; Vatansever, R.; Kurtoglu, K.Y.; Koc, I.; Öztürk, M.X.; Anjum, N.A. Identification and comparative analysis of $\mathrm{H}_{2} \mathrm{O}_{2}$-scavenging enzymes (ascorbate peroxidase and glutathione peroxidase) in selected plants employing bioinformatics approaches. Front. Plant Sci. 2016, 7, 301. [CrossRef] [PubMed]

160. Chew, O.; Whelan, J.; Millar, A.H. Molecular definition of the ascorbate-glutathione cycle in Arabidopsis mitochondria reveals dual targeting of antioxidant defenses in plants. J. Biol. Chem. 2003, 278, 46869-46877. [CrossRef] [PubMed]

161. Yang, Y.; Han, C.; Liu, Q.; Lin, B.; Wang, J. Effect of drought and low light on growth and enzymatic antioxidant system of Picea asperata seedlings. Acta Physiol. Plant. 2008, 30, 433-440. [CrossRef]

162. Koussevitzky, S.; Suzuki, N.; Huntington, S.; Armijo, L.; Sha, W.; Cortes, D.; Shulaev, V.; Mittler, R. Ascorbate peroxidase 1 plays a key role in the response of Arabidopsis thaliana to stress combination. J. Biol. Chem. 2008, 283, 34197-34203. [CrossRef]

163. Anjum, N.A.; Gill, S.S.; Gill, R.; Hasanuzzaman, M.; Duarte, A.C.; Pereira, E.; Ahmad, I.; Tuteja, R.; Tuteja, N. Metal/metalloid stress tolerance in plants: Role of ascorbate, its redox couple, and associated enzymes. Protoplasma 2014, 251, 1265-1283. [CrossRef]

164. Bela, K.; Horváth, E.; Gallé, Á.; Szabados, L.; Tari, I.; Csiszár, J. Plant glutathione peroxidases: Emerging role of the antioxidant enzymes in plant development and stress responses. J. Plant Physiol. 2015, 176, 192-201. [CrossRef]

165. Rouhier, N.; Jacquot, J.-P. The plant multigenic family of thiol peroxidases. Free Radic. Biol. Med. 2005, 38, 1413-1421. [CrossRef]

166. Navrot, N.; Collin, V.; Gualberto, J.; Gelhaye, E.; Hirasawa, M.; Rey, P.; Knaff, D.B.; Issakidis, E.; Jacquot, J.P.; Rouhier, N. Plant glutathione peroxidases are functional peroxiredoxins distributed in several subcellular compartments and regulated during biotic and abiotic stresses. Plant Physiol. 2006, 142, 1364-1379. [CrossRef]

167. Rizhsky, L.; Hallak-Herr, E.; Van Breusegem, F.; Rachmilevitch, S.; Barr, J.E.; Rodermel, S.; Inzé, D.; Mittler, R. Double antisense plants lacking ascorbate peroxidase and catalase are less sensitive to oxidative stress than single antisense plants lacking ascorbate peroxidase or catalase. Plant J. 2002, 32, 329-342. [CrossRef]

168. Foyer, C.; Lelandais, M.; Galap, C.; Kunert, K.J. Effects of elevated cytosolic glutathione reductase activity on the cellular glutathione pool and photosynthesis in leaves under normal and stress conditions. Plant Physiol. 1991, 97, 863-872. [CrossRef] 
169. Khan, T.; Mazid, M.; Mohammad, F. A review of ascorbic acid potentialities against oxidative stress induced in plants. J. Agrobiol. 2011, 28, 97-111. [CrossRef]

170. Tommasi, F.; Paciolla, C.; de Pinto, M.C.; De Gara, L. A comparative study of glutathione and ascorbate metabolism during germination of Pinus pinea L. seeds. J. Exp. Bot. 2001, 52, 1647-1654. [CrossRef] [PubMed]

171. Alamri, S.A.; Siddiqui, M.H.; Al-Khaishany, M.Y.Y.; Nasir Khan, M.; Ali, H.M.; Alaraidh, I.A.; Alsahli, A.A.; Al-Rabiah, H.; Mateen, M. Ascorbic acid improves the tolerance of wheat plants to lead toxicity. J. Plant Interact. 2018, 13, 409-419. [CrossRef]

172. Ahmad, I.; Basra, S.M.A.; Wahid, A. Exogenous application of ascorbic acid, salicylic acid and hydrogen peroxide improves the productivity of hybrid maize at low temperature stress. Int. J. Agric. Biol. 2014, 16, 825-830.

173. Conklin, P.L.; Barth, C. Ascorbic acid, a familiar small molecule intertwined in the response of plants to ozone, pathogens, and the onset of senescence. Plant Cell Environ. 2004, 27, 959-970. [CrossRef]

174. Noctor, G.; Foyer, C.H. Ascorbate and glutathione: Keeping active oxygen under control. Annu. Rev. Plant Physiol. Plant Mol. Biol. 1998, 49, 249-279. [CrossRef]

175. Larson, R.A. The antioxidants of higher plants. Phytochemistry 1988, 27, 969-978. [CrossRef]

176. Jiménez, A.; Hernández, J.A.; Pastori, G.; del Río, L.A.; Sevilla, F. Role of the ascorbate-glutathione cycle of mitochondria and peroxisomes in the senescence of pea leaves. Plant Physiol. 1998, 118, 1327-1335. [CrossRef]

177. Foyer, C.H.; Noctor, G. Redox homeostasis and antioxidant signaling: A metabolic interface between stress perception and physiological responses. Plant Cell 2005, 17, 1866-1875. [CrossRef]

178. Tausz, M.; Šircelj, H.; Grill, D. The glutathione system as a stress marker in plant ecophysiology: Is a stress-response concept valid? J. Exp. Bot. 2004, 55, 1955-1962. [CrossRef]

179. Creissen, G.; Firmin, J.; Fryer, M.; Kular, B.; Leyland, N.; Reynolds, H.; Pastori, G.; Wellburn, F.; Baker, N.; Wellburn, A.; et al. Elevated glutathione biosynthetic capacity in the chloroplasts of transgenic tobacco plants paradoxically causes increased oxidative stress. Plant Cell 1999, 11, 1277-1291. [CrossRef] [PubMed]

180. Pietrini, F.; Iannelli, M.A.; Pasqualini, S.; Massacci, A. Interaction of cadmium with glutathione and photosynthesis in developing leaves and chloroplasts of Phragmites australis (Cav.) Trin. ex Steudel. Plant Physiol. 2003, 133, 829-837. [CrossRef]

181. Zingg, J.-M.; Azzi, A. Non-antioxidant activities of vitamin E. Curr. Med. Chem. 2004, 11, 1113-1133. [CrossRef]

182. Holländer-Czytko, H.; Grabowski, J.; Sandorf, I.; Weckermann, K.; Weiler, E.W. Tocopherol content and activities of tyrosine aminotransferase and cystine lyase in Arabidopsis under stress conditions. J. Plant Physiol. 2005, 162, 767-770. [CrossRef]

183. Senaratna, T.; Gusse, J.F.; McKersie, B.D. Age-induced changes in cellular membranes of imbibed soybean seed axes. Physiol. Plant. 1988, 73, 85-91. [CrossRef]

184. Hamad, I.; Arda, N.; Pekmez, M.; Karaer, S.; Temizkan, G. Intracellular scavenging activity of Trolox (6-hydroxy-2,5,7,8tetramethylchromane-2-carboxylic acid) in the fission yeast, Schizosaccharomyces pombe. J. Nat. Sci. Biol. Med. 2010, 1, 16-21. [CrossRef] [PubMed]

185. Lúcio, M.; Nunes, C.; Gaspar, D.; Ferreira, H.; Lima, J.L.F.C.; Reis, S. Antioxidant activity of vitamin E and Trolox: Understanding of the factors that govern lipid peroxidation studies in vitro. Food Biophys. 2009, 4, 312-320. [CrossRef]

186. Collins, A.R. Carotenoids and genomic stability. Mutat. Res.-Fundam. Mol. Mech. Mutagen. 2001, 475, 21-28. [CrossRef]

187. Haslam, E.; Cai, Y. Plant polyphenols (vegetable tannins): Gallic acid metabolism. Nat. Prod. Rep. 1994, 11, 41-66. [CrossRef]

188. Handique, J.G.; Baruah, J.B. Polyphenolic compounds: An overview. React. Funct. Polym. 2002, 52, 163-188. [CrossRef]

189. Ow, Y.-Y.; Stupans, I. Gallic acid and gallic acid derivatives: Effects on drug metabolizing enzymes. Curr. Drug Metab. 2005, 4, 241-248. [CrossRef]

190. Metodiewa, D.; Jaiswal, A.K.; Cenas, N.; Dickancaité, E.; Segura-Aguilar, J. Quercetin may act as a cytotoxic prooxidant after its metabolic activation to semiquinone and quinoidal product. Free Radic. Biol. Med. 1999, 26, 107-116. [CrossRef]

191. Sakagami, H.; Satoh, K. Prooxidant action of two antioxidants: Ascorbic acid and gallic acid. Anticancer Res. 1997, 17, 221-224. [PubMed]

192. Verma, S.; Singh, A.; Mishra, A. Gallic acid: Molecular rival of cancer. Environ. Toxicol. Pharmacol. 2013, 35, 473-485. [CrossRef]

193. Nakatani, N. Natural Antioxidants from Spices. In Phenolic Compounds in Food and Their Effects on Health II: Antioxidants and Cancer Prevention; Huang, M.T., Ho, C.T., Lee, C., Eds.; American Chemical Society: Washington, DC, USA, 1992; pp. 72-86.

194. Yen, G.C.; Der Duh, P.; Tsai, H.L. Antioxidant and pro-oxidant properties of ascorbic acid and gallic acid. Food Chem. 2002, 79, 307-313. [CrossRef]

195. Rakshit, A.; Singh, H.B. Advances in Seed Priming; Rakshit, A., Singh, H.B., Eds.; Springer: Singapore, 2018; ISBN 978-981-13-0031-8.

196. Paparella, S.; Araújo, S.S.; Rossi, G.; Wijayasinghe, M.; Carbonera, D.; Balestrazzi, A. Seed priming: State of the art and new perspectives. Plant Cell Rep. 2015, 34, 1281-1293. [CrossRef]

197. Evenari, M. Seed physiology: Its history from antiquity to the beginning of the 20th century. Bot. Rev. 1984, 50, 119-142. [CrossRef]

198. Waqas, M.; Korres, N.E.; Khan, M.D.; Nizami, A.; Deeba, F.; Ali, I.; Hussain, H. Advances in the concept and methods of seed priming. In Priming and Pretreatment of Seeds and Seedlings; Hasanuzzaman, M., Fotopoulos, V., Eds.; Springer: Singapore, 2019; pp. 11-41. ISBN 978-981-13-8624-4.

199. Darwin, C.R. Effect of salt-water on the germination of seeds. Gardeners' Chron. Agric. Gazet. 1855, $47,773$.

200. May, L.H.; Milthorpe, E.J.; Milthorpe, F.L. Pre-sowing hardening of plants to drought. In Field Crop Abstracts; CABI: Wallingford, UK, 1962; pp. 93-98. 
201. Heydecker, W. Germination of an idea: The priming of seeds. Ph.D. Thesis, School of Agriculture Research, University of Nottingham, Nottingham, UK, 1973; pp. 50-67.

202. Malnassy, P.G. Physiological and biochemical studies on a treatment hastening the germination of seeds at low temperatures. Ph.D. Thesis, The State University of New Jersey, Rutgers, NJ, USA, 1971.

203. Sivasubramaniam, K.; Geetha, R.; Sujatha, K.; Raja, K.; Sripunitha, A.; Selvarani, R. Seed Priming: Triumphs and tribulations. Physiology 2011, 98, 197-209.

204. Rowse, H.R. Methods of priming seed. U.S. Patent 5,119,589, 1992.

205. Bradford, K.J. Manipulation of seed water relations via osmotic priming to improve germination under stress conditions. HortScience 1986, 21, 1105.

206. Parera, C.A.; Cantliffe, D.J. Presowing Seed Priming. In Horticultural Reviews; John Wiley \& Sons, Inc.: Oxford, UK, 1994; Volume 16, pp. 109-141. ISBN 9780470650561.

207. Singh, V.K.; Singh, R.; Tripathi, S.; Devi, R.S.; Srivastava, P.; Singh, P.; Kumar, A.; Bhadouria, R. Seed priming: State of the art and new perspectives in the era of climate change. In Climate Change and Soil Interactions; Prasad, M.N.V., Pietrzykowski, M., Eds.; Elsevier: Amsterdam, The Netherlands, 2020; pp. 143-170. ISBN 9780128180327.

208. Beckers, G.J.; Conrath, U. Priming for stress resistance: From the lab to the field. Curr. Opin. Plant Biol. 2007, $10,425-431$. [CrossRef]

209. Waterworth, W.M.; Bray, C.M.; West, C.E. The importance of safeguarding genome integrity in germination and seed longevity. J. Exp. Bot. 2015, 66, 3549-3558. [CrossRef]

210. Waterworth, W.M.; Masnavi, G.; Bhardwaj, R.M.; Jiang, Q.; Bray, C.M.; West, C.E. A plant DNA ligase is an important determinant of seed longevity. Plant J. 2010, 63, 848-860. [CrossRef]

211. Vonarx, E.J.; Mitchell, H.L.; Karthikeyan, R.; Chatterjee, I.; Kunz, B.A. DNA repair in higher plants. Mutat. Res. 1998, 400, 187-200. [CrossRef]

212. El-Maarouf-Bouteau, H.; Meimoun, P.; Job, C.; Job, D.; Bailly, C. Role of protein and mRNA oxidation in seed dormancy and germination. Front. Plant Sci. 2013, 4, 77. [CrossRef]

213. Bailly, C.; Benamar, A.; Corbineau, F.; Côme, D. Antioxidant systems in sunflower (Helianthus annuus L.) seeds as affected by priming. Seed Sci. Res. 2000, 10, 35-42. [CrossRef]

214. Hsu, C.C.; Chen, C.L.; Chen, J.J.; Sung, J.M. Accelerated aging-enhanced lipid peroxidation in bitter gourd seeds and effects of priming and hot water soaking treatments. Sci. Hortic. 2003, 98, 201-212. [CrossRef]

215. Farooq, M.; Basra, S.M.A.; Afzal, I.; Khaliq, A. Optimization of hydropriming techniques for rice seed invigoration. Seed Sci. Technol. 2006, 34, 507-512. [CrossRef]

216. Ghassemi-Golezani, K.; Esmaeilpour, B. The Effect of salt priming on the performance of differentially matured cucumber (Cucumis sativus) seeds. Not. Bot. Hort. Agrobot. 2008, 36, 67-70. [CrossRef]

217. Mirmazloum, I.; Kiss, A.; Erdélyi, É.; Ladányi, M.; Németh, É.Z.; Radácsi, P. The effect of osmopriming on seed germination and early seedling characteristics of Carum carvi L. Agriculture 2020, 10, 94. [CrossRef]

218. Rajjou, L.; Debeaujon, I. Seed longevity: Survival and maintenance of high germination ability of dry seeds. Comptes Rendus-Biol. 2008, 331, 796-805. [CrossRef]

219. Chandra, J.; Sershen; Varghese, B.; Keshavkant, S. The potential of ROS inhibitors and hydrated storage in improving the storability of recalcitrant Madhuca latifolia seeds. Seed Sci. Technol. 2019, 47, 33-45. [CrossRef]

220. Ashraf, M.A.; Akbar, A.; Askari, S.H.; Iqbal, M.; Rasheed, R.; Hussain, I. Recent advances in abiotic stress tolerance of plants through chemical priming: An overview. In Advances in Seed Priming; Rakshit, A., Singh, H.B., Eds.; Springer: Singapore, 2018; pp. 51-79. ISBN 9789811300325.

221. Varier, A.; Vari, A.K.; Dadlani, M. The subcellular basis of seed priming. Curr. Sci. 2010, 99, 450-456.

222. Cantliffe, D.J. Priming of lettuce seed for early and uniform emergence under conditions of environmental stress. Acta Hortic. 1981, 29-38. [CrossRef]

223. Bradford, K.J.; Steiner, J.J.; Trawatha, S.E. Seed priming influence on germination and emergence of pepper seed lots. Crop Sci. 1990, 30, 718-721. [CrossRef]

224. Khan, A.A.; Peck, N.H.; Samimy, C. Seed osmoconditioning: Physiological and biochemical changes. Isr. J. Bot. 1980, 29 , 133-144. [CrossRef]

225. Taylor, A.G.; Klein, D.E.; Whitlow, T.H. SMP: Solid matrix priming of seeds. Sci. Hortic. 1988, 37, 1-11. [CrossRef]

226. Mondal, S.; Vijai, P.; Bose, B. Role of seed hardening in rice variety swarna (MTU 7029). Res. J. Seed Sci. 2011, 4, 157-165. [CrossRef]

227. Matsushima, K.-I.; Sakagami, J.-I. Effects of seed hydropriming on germination and seedling vigour during emergence of rice under different soil moisture conditions. Am. J. Plant Sci. 2013, 4, 1584-1593. [CrossRef]

228. Forti, C.; Ottobrino, V.; Bassolino, L.; Toppino, L.; Rotino, G.L.; Pagano, A.; Macovei, A.; Balestrazzi, A. Molecular dynamics of pre-germinative metabolism in primed eggplant (Solanum melongena L.) seeds. Hortic. Res. 2020, 7, 87. [CrossRef]

229. Basra, S.M.A.; Farooq, M.; Tabassam, R.; Ahmad, N. Physiological and biochemical aspects of pre-sowing seed treatments in fine rice (Oryza sativa L.). Seed Sci. Technol. 2005, 33, 623-628. [CrossRef]

230. Farooq, M.; Basra, S.M.A.; Abid Karim, H.; Afzal, I. Optimization of seed hardening techniques for rice seed invigoration. Emir. J. Food Agric. 2004, 16, 48-58. [CrossRef]

231. Solaimalai, A.; Subburamu, K. Seed hardening for field crops-A review. Agric. Rev. 2004, 25, 129-140. 
232. Akbar, M. Studies on Seed Priming and Fungicide in Pearl Millet under Dry Land Conditions. Ph.D. Thesis, NWFP Agricultural University, Peshawar, Pakistan, 2008.

233. Alvarado, A.D.; Bradford, K.J. Priming and storage of tomato (Lycopersicon lycopersicum) seeds. I. Effects of storage temperature on germination rate and viability. Seed Sci. Technol. 1988, 16, 601-612.

234. Bekendam, J.; van Pijlen, J.G.; Kraak, H.L. The effect of priming on the rate and uniformity of germination of endive seed. Acta Hortic. 1987, 209-218. [CrossRef]

235. Weges, R. Physiological Analysis of Methods to Relieve Dormancy of Lettuce Seeds. Ph.D. Thesis, Wageningen Agricultural University, Wageningen, The Netherlands, 1987.

236. Tarquis, A.M.; Bradford, K.J. Prehydration and priming treatments that advance germination also increase the rate of deterioration of lettuce seeds. J. Exp. Bot. 1992, 43, 307-317. [CrossRef]

237. van Pijlen, J.G.; Groot, S.P.C.; Kraak, H.L.; Bergervoet, J.H.W.; Bino, R.J. Effects of pre-storage hydration treatments on germination performance, moisture content, DNA synthesis and controlled deterioration tolerance of tomato (Lycopersicon esculentum Mill.) seeds. Seed Sci. Res. 1996, 6, 57-63. [CrossRef]

238. Brancalion, P.H.S.; Novembre, A.D.L.C.; Rodrigues, R.R.; Tay, D. Priming of Mimosa bimucronata seeds-A tropical tree species from Brazil. Acta Hortic. 2008, 782, 163-168. [CrossRef]

239. Mahakham, W.; Sarmah, A.K.; Maensiri, S.; Theerakulpisut, P. Nanopriming technology for enhancing germination and starch metabolism of aged rice seeds using phytosynthesized silver nanoparticles. Sci. Rep. 2017, 7, 8263. [CrossRef] [PubMed]

240. de Sousa Araújo, S.; Paparella, S.; Dondi, D.; Bentivoglio, A.; Carbonera, D.; Balestrazzi, A. Physical methods for seed invigoration: Advantages and challenges in seed technology. Front. Plant Sci. 2016, 7, 646. [CrossRef]

241. Harris, D.; Raghuwanshi, B.S.; Gangwar, J.S.; Singh, S.C.; Joshi, K.D.; Rashid, A.; Hollington, P.A. Participatory evaluation by farmers of on-farm seed priming in wheat in India, Nepal and Pakistan. Exp. Agric. 2001, 37, 403-415. [CrossRef]

242. Taylor, A.G.; Allen, P.S.; Bennett, M.A.; Bradford, K.J.; Burris, J.S.; Misra, M.K. Seed enhancements. Seed Sci. Res. 1998, 8, $245-256$. [CrossRef]

243. Kaur, S.; Gupta, A.K.; Kaur, N. Effect of osmo- and hydropriming of chickpea seeds on seedling growth and carbohydrate metabolism under water deficit stress. Plant Growth Regul. 2002, 37, 17-22. [CrossRef]

244. Yan, M. Hydropriming promotes germination of aged napa cabbage seeds. Seed Sci. Technol. 2015, 43, 303-307. [CrossRef]

245. Bennett, M.A.; Fritz, V.A.; Callan, N.W. Impact of seed treatments on crop stand establishment. Horttechnology 2018, 2, 345-349. [CrossRef]

246. Adetunji, A.E.; Sershen; Varghese, B.; Pammenter, N.W. Effects of inorganic salt solutions on vigour, viability, oxidative metabolism and germination enzymes in aged cabbage and lettuce seeds. Plants 2020, 9, 1164. [CrossRef]

247. Singh, A.; Dahiru, R.; Musa, M.; Sani Haliru, B. Effect of osmopriming duration on germination, emergence, and early growth of cowpea (Vigna unguiculata (L.) Walp.) in the sudan savanna of Nigeria. Int. J. Agron. 2014, 2014, 1-4. [CrossRef]

248. Fatokun, K.; Beckett, R.P.; Varghese, B.; Cloete, J.; Pammenter, N.W. Influence of cathodic water invigoration on the emergence and subsequent growth of controlled deteriorated pea and pumpkin seeds. Plants 2020, 9, 955. [CrossRef]

249. Batool, A.; Ziaf, K.; Amjad, M. Effect of halo-priming on germination and vigor index of cabbage (Brassica oleracea var. capitata). J. Environ. Agric. Sci. 2015, 2, 7.

250. Abdolahi, M.; Andelibi, B.; Zangani, E.; Shekari, F.; Jamaati-E-Somarin, S. Effect of accelerated aging and priming on seed germination of rapeseed (Brassica napus L.) cultivars. Int. Res. J. Appl. Basic Sci. 2012, 3, 499-508.

251. Carrozzi, L.E.; Creus, C.M.; Barassi, C.A.; Monterubbianesi, G.; Di Benedetto, A. Reparation of aged lettuce (Lactuca sativa) seeds by osmotic priming and Azospirillum brasilense inoculation. Botany 2012, 90, 1093-1102. [CrossRef]

252. Moradi, A.; Younesi, O. Effects of osmo- and hydro-priming on seed parameters of grain sorghum (Sorghum bicolor L.). Aust. J. Basic Appl. Sci. 2009, 3, 1696-1700.

253. Gupta, D.K.; Palma, J.M.; Corpas, F.J. Redox State as a Central Regulator of Plant-Cell Stress Responses; Gupta, D.K., Palma, J.M., Corpas, F.J., Eds.; Springer International Publishing: Cham, Switzerland, 2016; ISBN 978-3-319-44080-4.

254. Kumar, S.R.; Mohanapriya, G.; Sathishkumar, R. Abiotic stress-induced redox changes and programmed cell death in plants-A path to survival or death? In Redox State as a Central Regulator of Plant-Cell Stress Responses; Springer: Cham, Switzerland, 2016; pp. 233-252. ISBN 9783319440811.

255. Schafer, F.Q.; Buettner, G.R. Redox state and redox environment in biology. In Signal Transduction by Reactive Oxygen and Nitrogen Species: Pathways and Chemical Principles; Kluwer Academic Publishers: Dordrecht, The Netherlands, 2006 ; pp. 1-14.

256. Miller, G.; Suzuki, N.; Ciftci-Yilmaz, S.; Mittler, R. Reactive oxygen species homeostasis and signalling during drought and salinity stresses. Plant Cell Environ. 2010, 33, 453-467. [CrossRef]

257. Draganić, I.; Lekić, S. Seed priming with antioxidants improves sunflower seed germination and seedling growth under unfavorable germination conditions. Turkish J. Agric. For. 2012, 36, 421-428. [CrossRef]

258. Adetunji, A.E.; Sershen; Varghese, B.; Pammenter, N. Effects of exogenous application of five antioxidants on vigour, viability, oxidative metabolism and germination enzymes in aged cabbage and lettuce seeds. S. Afr. J. Bot. 2021, 137, 85-97. [CrossRef]

259. Adetunji, A.E.; Sershen; Varghese, B.; Pammenter, N.W. Exogenous antioxidants enhance seedling growth and yield of artificially aged cabbage and lettuce seeds. Horticulturae 2021, 7, 274. [CrossRef]

260. Burguieres, E.; McCue, P.; Kwon, Y.I.; Shetty, K. Effect of vitamin C and folic acid on seed vigour response and phenolic-linked antioxidant activity. Bioresour. Technol. 2007, 98, 1393-1404. [CrossRef] 
261. Yan, H.-F.; Mao, P.-S.; Sun, Y.; Li, M.-L. Impacts of ascorbic acid on germination, antioxidant enzymes and ultrastructure of embryo cells of aged Elymus sibiricus seeds with different moisture contents. Int. J. Agric. Biol. 2016, 18, 176-183. [CrossRef]

262. Afzal, I.; Basra, S.M.A.; Hameed, A.; Farooq, M. Physiological enhancements for alleviation of salt stress in wheat. Pakistan J. Bot. 2006, 38, 1649-1659.

263. Bhattacharjee, A.; Gupta, K. Effect of dikegulac-sodium, a growth retardant, on the viability of sunflower seeds. Seed Sci. Technol. $1985,13,165-174$.

264. Dey, G.; Mukherjee, R.K. Invigoration of dry seeds with physiologically active chemicals in organic solvents. Seed Sci. Technol. 1988, 16, 145-153.

265. Bhattacharjee, A.; Bhattacharyya, R.N. Prolongation of seed viability of Oryza sativa L. Seed Sci. Technol. 1989, 17, 309-316.

266. Ugena, L.; Hýlová, A.; Podlešáková, K.; Humplík, J.F.; Doležal, K.; De Diego, N.; Spíchal, L. Characterization of biostimulant mode of action using novel multi-trait high-throughput screening of arabidopsis germination and rosette growth. Front. Plant Sci. 2018, 9, 1327. [CrossRef]

267. Rouphael, Y.; Colla, G. Editorial: Biostimulants in agriculture. Front. Plant Sci. 2020, 11, 40. [CrossRef]

268. Sreekissoon, A.; Finnie, J.F.; Van Staden, J. Effects of smoke water on germination, seedling vigour and growth of Sceletium tortuosum. S. Afr. J. Bot. 2021, 139, 427-431. [CrossRef]

269. Gupta, G.P. Role of global climate change in crop yield reductions. In Journal of the Air Pollution Control Association; Saxena, P., Srivastava, A., Eds.; Springer: Singapore, 2020; Volume 13, pp. 87-113. ISBN 9789811534805.

270. Zhou, J.; Teixeira da Silva, J.; Ma, G. Effects of smoke water and karrikin on seed germination of 13 species growing in China. Open Life Sci. 2014, 9, 1108-1116. [CrossRef]

271. Makhaye, G.; Aremu, A.O.; Gerrano, A.S.; Tesfay, S.; Du Plooy, C.P.; Amoo, S.O. Biopriming with seaweed extract and microbialbased commercial biostimulants influences seed germination of five Abelmoschus esculentus genotypes. Plants 2021, $10,1327$. [CrossRef] [PubMed]

272. Masondo, N.A.; Kulkarni, M.G.; Finnie, J.F.; Van Staden, J. Influence of biostimulants-seed-priming on Ceratotheca triloba germination and seedling growth under low temperatures, low osmotic potential and salinity stress. Ecotoxicol. Environ. Saf. 2018, 147, 43-48. [CrossRef]

273. Johnson, R.; Puthur, J.T. Biostimulant priming in Oryza sativa: A novel approach to reprogram the functional biology under nutrient-deficient soil. Cereal Res. Commun. 2021, 1-8. [CrossRef]

274. Parisi, C.; Vigani, M.; Rodríguez-Cerezo, E. Agricultural nanotechnologies: What are the current possibilities? Nano Today 2015, 10, 124-127. [CrossRef]

275. Servin, A.; Elmer, W.; Mukherjee, A.; De la Torre-Roche, R.; Hamdi, H.; White, J.C.; Bindraban, P.; Dimkpa, C. A review of the use of engineered nanomaterials to suppress plant disease and enhance crop yield. J. Nanoparticle Res. 2015, 17, 92. [CrossRef]

276. Fraceto, L.F.; Grillo, R.; de Medeiros, G.A.; Scognamiglio, V.; Rea, G.; Bartolucci, C. Nanotechnology in agriculture: Which innovation potential does it have? Front. Environ. Sci. 2016, 4, 20. [CrossRef]

277. Sundaria, N.; Singh, M.; Upreti, P.; Chauhan, R.P.; Jaiswal, J.P.; Kumar, A. Seed priming with iron oxide nanoparticles triggers iron acquisition and biofortification in wheat (Triticum aestivum L.) grains. J. Plant Growth Regul. 2019, 38, 122-131. [CrossRef]

278. Hirota, N.; Nakagawa, J.; Kitazawa, K. Effects of a magnetic field on the germination of plants. J. Appl. Phys. 1999, 85, 5717-5719. [CrossRef]

279. Aladjadjiyan, A. Influence of stationary magnetic field on lentil seeds. Int. Agrophys. 2010, 24, 321-324.

280. Teixeira da Silva, J.A.; Dobránszki, J. Magnetic fields: How is plant growth and development impacted? Protoplasma 2016, 253, 231-248. [CrossRef] [PubMed]

281. Bilalis, D.J.; Katsenios, N.; Efthimiadou, A.; Karkanis, A.; Efthimiadis, P. Investigation of pulsed electromagnetic field as a novel organic pre-sowing method on germination and initial growth stages of cotton. Electromagn. Biol. Med. 2012, 31, 143-150. [CrossRef]

282. Baby, S.M.; Narayanaswamy, G.K.; Anand, A. Superoxide radical production and performance index of photosystem II in leaves from magnetoprimed soybean seeds. Plant Signal. Behav. 2011, 6, 1635-1637. [CrossRef] [PubMed]

283. Vashisth, A.; Nagarajan, S. Effect on germination and early growth characteristics in sunflower (Helianthus annuus) seeds exposed to static magnetic field. J. Plant Physiol. 2010, 167, 149-156. [CrossRef]

284. Marcu, D.; Cristea, V.; Daraban, L. Dose-dependent effects of gamma radiation on lettuce (Lactuca sativa var. capitata) seedlings. Int. J. Radiat. Biol. 2013, 89, 219-223. [CrossRef] [PubMed]

285. Ouhibi, C.; Attia, H.; Rebah, F.; Msilini, N.; Chebbi, M.; Aarrouf, J.; Urban, L.; Lachaal, M. Salt stress mitigation by seed priming with UV-C in lettuce plants: Growth, antioxidant activity and phenolic compounds. Plant Physiol. Biochem. 2014, 83, 126-133. [CrossRef] [PubMed]

286. Thomas, D.T.; Puthur, J.T. Amplification of abiotic stress tolerance potential in rice seedlings with a low dose of UV-B seed priming. Funct. Plant Biol. 2019, 46, 455-466. [CrossRef]

287. Al-Enezi, N.A.; Al-Bahrany, A.M.; Al-Khayri, J.M. Effect of X-irradiation on date palm seed germination and seedling growth. Emir. J. Food Agric. 2012, 24, 415-424.

288. De Micco, V.; Paradiso, R.; Aronne, G.; De Pascale, S.; Quarto, M.; Arena, C. Leaf anatomy and photochemical behaviour of Solanum lycopersicum L. Plants from seeds irradiated with low-LET ionising radiation. Sci. World J. 2014, 2014. [CrossRef] 
289. Randhir, R.; Shetty, K. Microwave-induced stimulation of L-DOPA, phenolics and antioxidant activity in fava bean (Vicia faba) for Parkinson's diet. Process Biochem. 2004, 39, 1775-1784. [CrossRef]

290. Han, F. The effect of microwave treatment on germination, vigour and health of China aster (Callistephus chinensis Nees.) seeds. J. Agric. Sci. 2010, 2, 201-210. [CrossRef]

291. UN General Assembly. Transforming Our World: The 2030 Agenda for Sustainable Development; UN: New York, NY, USA, 2015; Report No. A/RES/70/1. 